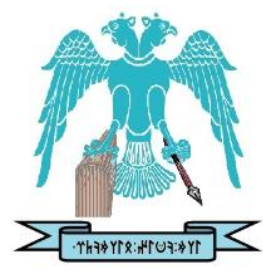

JOURNAL OF ENERGY SYSTEMS

$2021,5(2)$

\title{
Renewable energy development in rural areas of Uttar Pradesh: Current status, technologies and $\mathrm{CO}_{2}$ mitigation analysis
}

\author{
Akanksha Sharma \\ Amity University, Electrical \& Electronics Engineering Department, India, \\ akanksha.sharma2610@gmail.com \\ H.P Singh \\ Amity University, Electrical \& Electronics Engineering Department, India, hpsingh2@amity.edu \\ R.K Viral \\ Amity University, Electrical \& Electronics Engineering Department, India, rviral@amity.edu \\ Naqui Anwer iD \\ Teri School of Advanced Studies, New Delhi, India, naquianwer@gmail.com
}

Abstract: The main factor having severe impact on lives of millions of people under the poverty line is energy deficiency. For the improvement of living and standard of education, there is a need to electrify the rural areas. India has an aim of achieving $175 \mathrm{GW}$ of renewable energy capacity by 2022 . The use of Renewable Energy Technologies propounds huge benefits to rural areas. Over the past two decades, rural electrification has been a continuous process, accelerated through various programs and schemes. Uttar Pradesh state of India, located in the north central region of the country is the most populous state. Energy demand is increasing steadily with the development of the state. With respect to limited conventional energy sources and increasing environmental pollution, production of energy based on renewable energy sources is given high priority. This paper presents the current status of renewable energy in the state, renewable energy-based options for rural electrification including the single technology-based systems, integrated and the hybrid energy systems depending on availability of resources. The current scenario of power generation and requirement is also discussed. A complete analysis of the current $\mathrm{CO}_{2}$ emission and the mitigation potential of different RESs are presented. Based on this the cost saving potential is performed.

Keywords: $\mathrm{CO}_{2}$ emission, Renewable energy, Rural electrification

Cite this paper as:
Sharma, A., Singh, H.P., Viral, R.K., \& Anwer N. Renewable energy development in rural areas of Uttar Pradesh: Current status, technologies and $\mathrm{CO}_{2}$ mitigation analysis. Journal of Energy Systems 2021, 5(2), 92-120, DOI: 10.30521/jes.816049 


\section{INTRODUCTION}

Currently, the predominant part of the global population around the world is residing in the developing nations which have a majority of rural un-electrified areas. The rural audiences or the customers have a huge diversity in their economic and social status with differences in both households and rural enterprise. These differences impact on both the demand for electricity and customer attitudes and preferences towards the various available sources of generation [1]. With a generation of 1,497 TWh, India is the third largest producer and third largest consumer of electricity in the world and has an installed power capacity reaching $347.22 \mathrm{GW}$ as of December 2018. The country also has the fifth largest installed capacity in the world. India is the world's first country using LEDs for all lighting needs by 2019 , thereby saving Rs 40,000 crores on an annual basis [2]. The country has experienced a growth of around 55.72 percent over the year FY18, with an electricity production of 1,201.543 BU which has reached to around 849.20 BU till now in FY19 [3]. In India, Wind energy is the largest source of renewable energy which accounts for around $35.14 \mathrm{GW}$ of the total installed renewable capacity of $74.08 \mathrm{GW}$. Solar energy is the second largest source which accounts for $25.21 \mathrm{GW}$ of the total installed capacity which is targeted to increase at around $100 \mathrm{GW}$ by 2022 [4]. In August 2015, Indian Government launched the Deen Dayal Upadhayaya Gram Jyoti Yojana (DDUGJY) in order to achieve $100 \%$ electrification in villages in 1000 days. India achieved the $100 \%$ electrification of the households in 25 states by December 2018 [5]. Only 10.48 lakh households were left to be electrified in 4 states of Assam, Rajasthan, Meghalaya and Chhattisgarh which were also electrified by April 2018, when Government declared every village in India as electrified but this means that at least $10 \%$ of households in every village were connected to the grid [5]. The electrification of different regions of India through the conventional and RESs is shown in Fig. 1 [6] and the electrification of different states of northern region is shown in Fig. 2 [6].

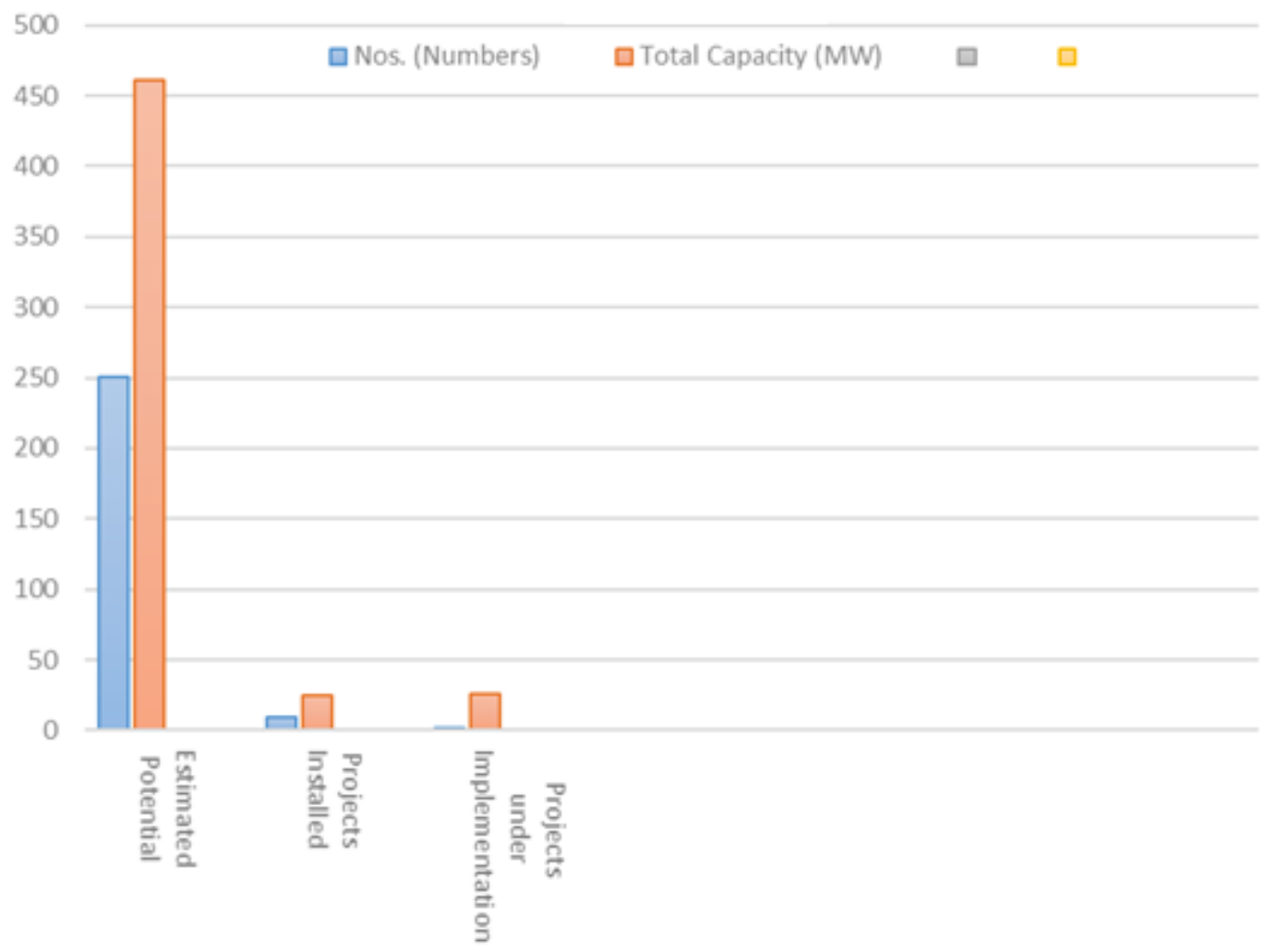

Figure 1. All installed capacity (MW) in different regions of all country as on 31.07.2019 [6]. 


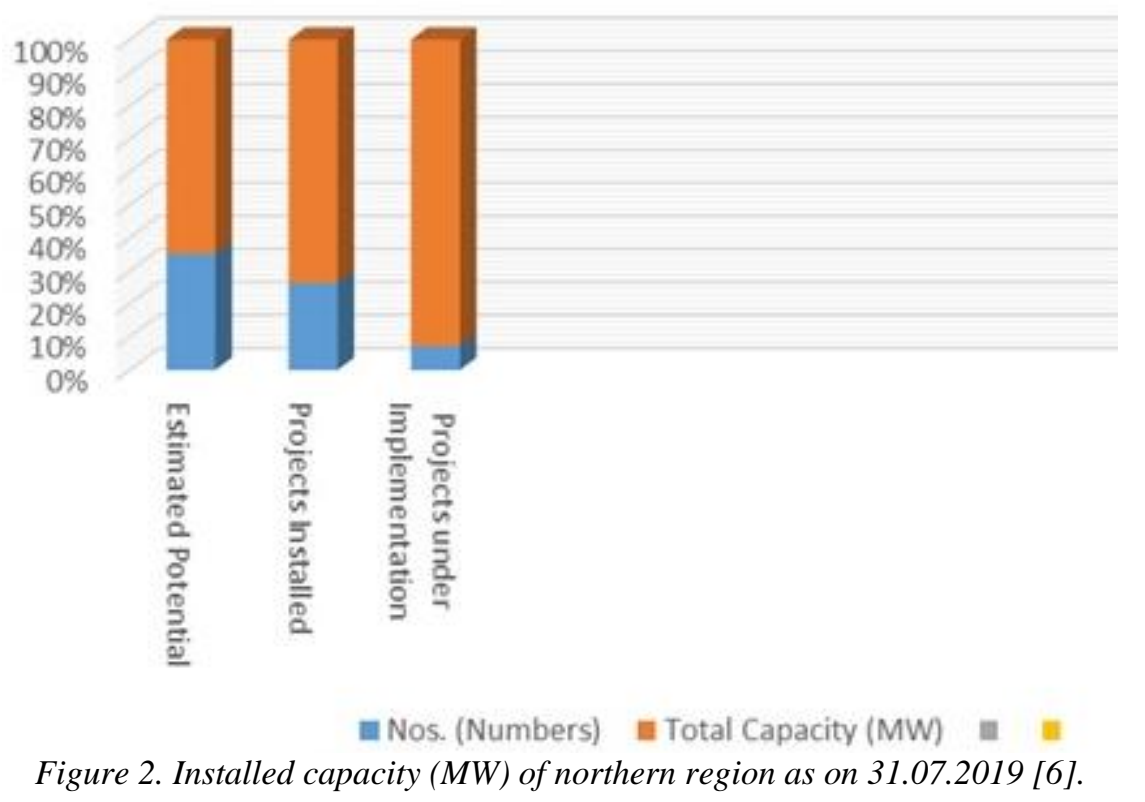

The Uttar Pradesh state of India is located in north central region of the country with a population of approximately 19.98 crores counted as the most populated state of India [7]. The state is divided into 75 districts and Lucknow is the capital. It also has good connectivity through 48 national highways, 6 airports \& rail links to all the major cities [8]. The geopolitical representation of Uttar Pradesh state is shown in Fig. 3.

In April 1983, government of Uttar Pradesh constituted Non- Conventional Energy Development Agency (NEDA) under the department of additional energy sources as an autonomous institution. The institute has been renamed as "Uttar Pradesh new and renewable energy development agency (UPNEDA)" [9]. Thermal Power contributed 18,642.21 MW to the state's total installed power generation capacity, followed by contribution of 3,368.63 MW by Hydropower, $289.48 \mathrm{MW}$ by nuclear power and3027.00MW are only the renewable powers [10]. The $24 \times 7$ power for all program is a joint initiative of the Government of India (GoI) and state governments, with the objective to provide $24 \times 7$ power to households, industry, commercial, and other consuming entities, and adequate power to the agricultural sector by 2019 [11]. The rise in the power capacity of the state through various years is shown in Fig. 4 [10].

As per the Census 2011, there are $77.37 \%$ of rural households in the state, out of which $76.23 \%$ are unelectrified [12]. In Uttar Pradesh state, according to the power for all reports, there are 2.89 crore rural households. Of these, 0.92 crore rural households already exist in distribution company's records and there are around 1.12 crore un-electrified households in the state [10].

To support planning for on-ground electricity access improvement in the state of Uttar Pradesh, the Council on Energy, Environment and Water (CEEW) presented certain findings and recommendations based on a household survey on energy access (referred to as ACCESS) conducted in collaboration with Columbia University in 2015. In Uttar Pradesh, at least five districts of the state - Azamgarh, Bijnour, Gorakhpur, Jhansi and Sultanpur - over 90 per cent of un-electrified households reside in electrified habitations [13]. Since the launch of Saubhagya Yojana, 74.4 Lakh willing households have been electrified and the state government has declared saturation of all 75 districts. According to the revised definition in the Electricity Act - 2003, a village is said to be electrified, if the public places like schools, Panchayat offices, health centers and 10 percent of the total households are connected to the grid i.e., it needs only one out of 10 households to have electricity supply for a village to be considered "electrified" [14]. District wise list of number of electrified households in Uttar Pradesh state as on January 2019 is given in Table 1 in Appendix 1 [15]. 


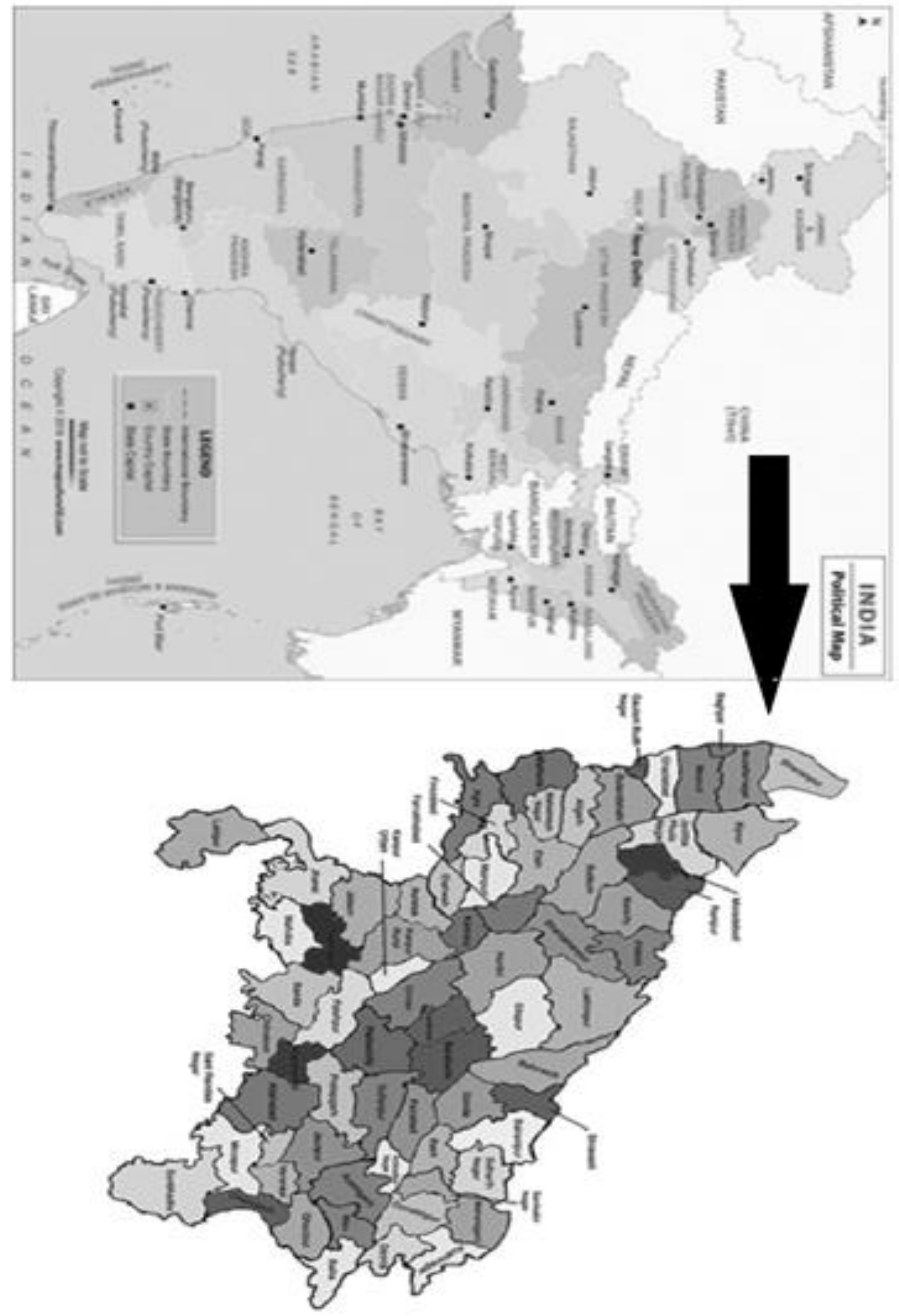

Figure 3. Geo-political representation of Uttar Pradesh state. 


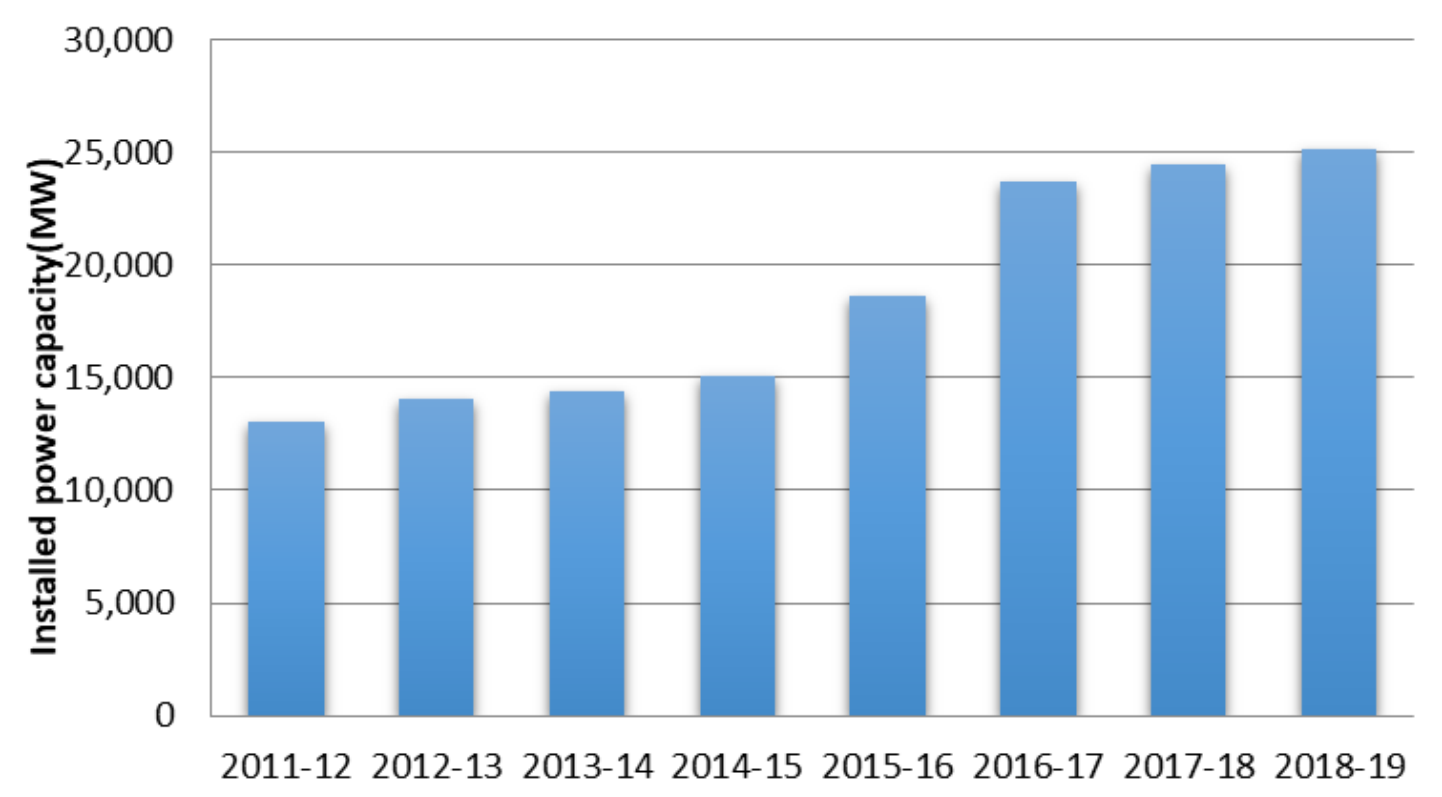

Figure 4. Year wise total installed power capacity growth in Uttar Pradesh state [10].

The main idea of this study lies in the fact to provide the complete information about the electrification of the Uttar Pradesh state. The main motivation behind this study is having complete knowledge about the electrification status of a state in a single article including all the recent data and information. In this paper, various strategies based on renewable energy are discussed for the electrification in Uttar Pradesh state. An approach has been rooted for the rural electrification of the state. A complete analysis of the current carbon dioxide $\left(\mathrm{CO}_{2}\right)$ emission in the state has been presented and possible $\mathrm{CO}_{2}$ mitigation potential along with the cost saving potential of various RESs available in the state has also been analyzed. Certain limitations and obstacles are also been presented that drift the RESs usage in the rural areas and also the possible solutions and recommendations to overcome these limitations.

\section{RENEWABLE ENERGY: PAST GROWTH, STATUS AND CURRENT PRACTICES IN UTTAR PRADESH}

According to the Load Generation Balancing Report (LGBR) - 2018 by the Central Electricity Authority (CEA), the current status shows that Uttar Pradesh is on a borderline of meeting its electricity needs on account of annual basis. It has also been warned in the report that the state could face a shortage of about $17.5 \%$ during the current financial year [16]. The report also says that in order to meet the required energy need, the state may arrange it from other surplus energy states. The peak demand of the state may reach up to 21,000 MW with a shortfall of 3,650 MW about $17.4 \%$ [16].

The state has a tremendous potential of increasing its biomass energy production in 97,589 villages and also is the largest producer of sugarcane and second largest producer of rice in India, the by-product bagasse and rice husk form abundant raw material base for power production [17]. The total amount provided as Central financial assistance (CFA) to the state for the promotion of various renewable energy schemes during 2018-2019 is 3432.21 lacs. The total renewable energy potential is shown in Fig. 5 [17]. 


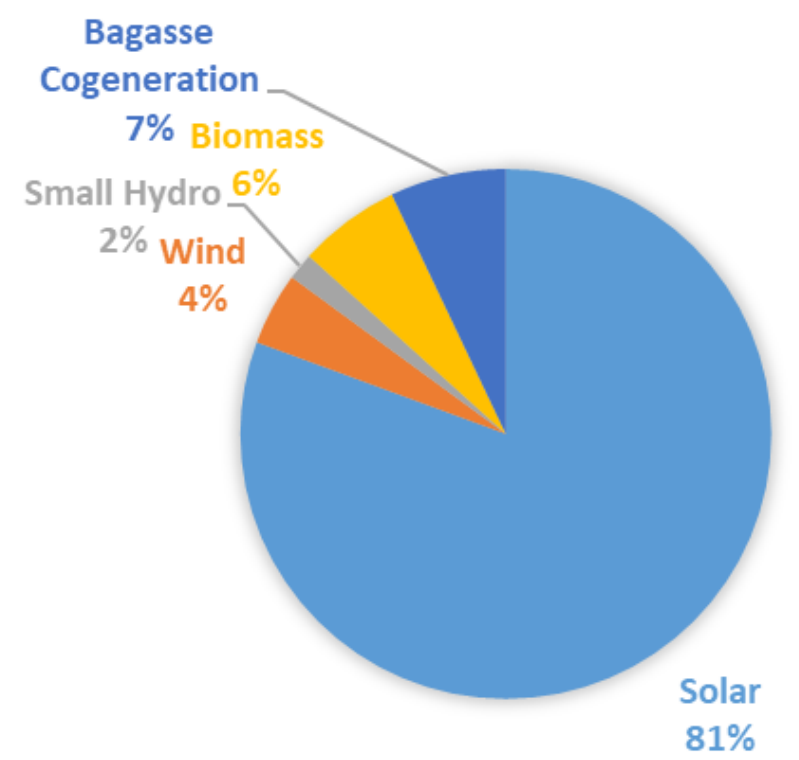

Figure 5. Renewable energy potential in Uttar Pradesh as on 2017-18 [17]

\subsection{Availability of RESs in the state}

Uttar Pradesh State is the most populated state of the country with a total area of 2, 40,928 $\mathrm{km}^{2}$. The state is divided into three distinct regions namely Himalayan in the North, Gangetic plain in the center and Vindhya hills and Plateau in the south. Out of the total area of the state $14,679 \mathrm{~km}^{2}$ area is covered by forest which constitutes $6.09 \%$ of the state's geographical area [12].

\subsubsection{Biomass Power Resources}

The basic economics of the state is based on agriculture and almost $65 \%$ population of the state is dependent on agricultural activities. Due to the large agricultural land available in the state which is 165.98 lac hectares, huge amount of residue is produced here [18]. This residue provides large potential of biomass feedstock that can be used for biogas production, cooking applications and electricity generation [19]. Uttar Pradesh is the only state which has utilized large part of its biomass potential, which can be attributed to its sugarcane industry, with cogeneration-based electricity generation [20,21].

\subsubsection{Hydro Power Resources}

Uttar Pradesh state is enriched with many rivers flowing through it like - Ganges, Yamuna, Ghagra, Gomti, Gandak, Sone and Sharda. The existing canal network and dam toes in the State too have potential of generating power through micro hydro power plants [22]. In the recent years, some of the northern and southern tributaries of Ganges and their minor feeder streams have been tamed, creating a few reservoirs [23].

\subsubsection{Wind Resources}

The state has a tropical monsoon climate, but because of the difference in altitudes there is a variation. The average temperature change is from $3-4{ }^{\circ} \mathrm{C}$ in January to $43-45^{\circ} \mathrm{C}$ in May and June. As per the Meso scale model-based study, the wind resource assessment conducted by Centre of Wind Energy Technology (C-WET), average wind speed is $4-80 \mathrm{~m} / \mathrm{s}$. The list of wind farm installed in the state is given in Table $1[24,25]$. 
Table 1. List of wind farm installed in Uttar Pradesh [24, 25].

\begin{tabular}{|c|c|c|c|}
\hline S. No & Wind farm with & District & Site Name \\
\hline 1 & & Lalitpur & Pipariya Jagir Bl. Birdha \\
\hline 2 & & Mirzapur & Domndganj Bl.Haliya \\
\hline 3 & & Raibarelly & Indraj/Khirnahee Bl.Bachrawan \\
\hline 4 & & Farukhabad & NaglaKail Bl.Nawabganj \\
\hline 5 & $50 \mathrm{~m}$ & Agra & Patsal-Rasolpur Bl. Fatehpursikri \\
\hline 6 & & Etawah & Kusauli-Khera Bl. Basrahar \\
\hline 7 & & Badaun & Gharhihardopatti Bl. Kadarchowk \\
\hline 8 & & Jhansi & Khatibaba Mandir Bl. Rajpur \\
\hline 9 & & Sonbhadra & Vill. Gharaaura Bl. Robertsganj \\
\hline 1 & & Gonda & Ahiwaranpurwa \\
\hline 2 & & Balrampur & Nageshwarjoth \\
\hline 3 & $80 \mathrm{~m}$ & Siddharthnagar & Choukonia \\
\hline 4 & & Shahjahanpur & Bijouria \\
\hline 5 & & Lakhimpur & Lakshmanpur \\
\hline
\end{tabular}

\subsubsection{Solar Resources}

According to the reports of the solar policy 2017, Uttar Pradesh has a solar energy potential of 22300 MW capacity and the state aspires to meet the energy requirements of the State and to achieve the solar power generation target, fixed by the ministry of new and renewable energy (MNRE), Government of India of $10700 \mathrm{MW}$ [26]. The annual average solar radiation for the state is about $4.27 \mathrm{kWh} / \mathrm{m}^{2} / \mathrm{day}$ [26]. According to the reports by the Centre for Environment and Energy Development (CEED), six cities in Uttar Pradesh state alone can generate $11.4 \mathrm{GW}$ of solar energy using $11 \%$ of their built-up area. Among these cities, Lucknow (3187 MW) has the maximum potential, followed by Kanpur (3010 MW) and Agra (1986 MW), whereas Gorakhpur (833 MW) has the lowest solar rooftop potential, followed by Allahabad and Meerut with 1577 MW and 900 MW, respectively [27,28].

\subsection{Renewable Energy Exploitation in the State}

In spite of a prodigious amount of RESs available to fulfill the electricity needs of the urban and rural area, the main problem arises in channeling these resources which can have its own advantages along with few disadvantages [30-32]. There seems to be negligible $\mathrm{CO}_{2}$ emissions during the use of biomass and biogas-based system, the $\mathrm{CO}_{2}$ emissions for the biomass gasifier-based system are $0.273 \mathrm{~kg}$ for $1 \mathrm{kWh}$ electricity and for the biogas digester-based system is $0.305 \mathrm{~kg}$ for $1 \mathrm{kWh}$ of electricity generation [33]. Wind system requires around $267.7 \mathrm{~m}^{2}$ area of land and the biogas system require around $144 \mathrm{~m}^{2}$ area of land for the installation of plant of $1 \mathrm{KW}$. The monthly average solar radiation in the state varies from $3.27 \mathrm{kWh} / \mathrm{m}^{2} /$ day in December to $7.01 \mathrm{kWh} / \mathrm{m}^{2} /$ day in May [27]. Based on the various technical aspects e.g., fuel used, size/ module (KW), electrical efficiency, overall efficiency, peak shaving, reliability, power quality and economical aspects e.g., installed cost $(\$ / \mathrm{kW})$, total maintenance cost $(\$ /$ $\mathrm{KW}$ ), the various RES technologies are compared and summarized in Table 3 given in Appendix 2 [27, 33-34] illustrating major merits \& demerits of each RES technology available in the state.

\section{MAJOR THRUST SECTOR (S) OF STATE: RELY UPON ENERGY}

\subsection{Electricity Generation in the state}

The total installed power capacity in India as on April 2019 is 356,100 MW out of which Uttar Pradesh has an installed capacity of 25,130.02 MW. The source wise installed capacity in the state is shown in Fig. 6. 


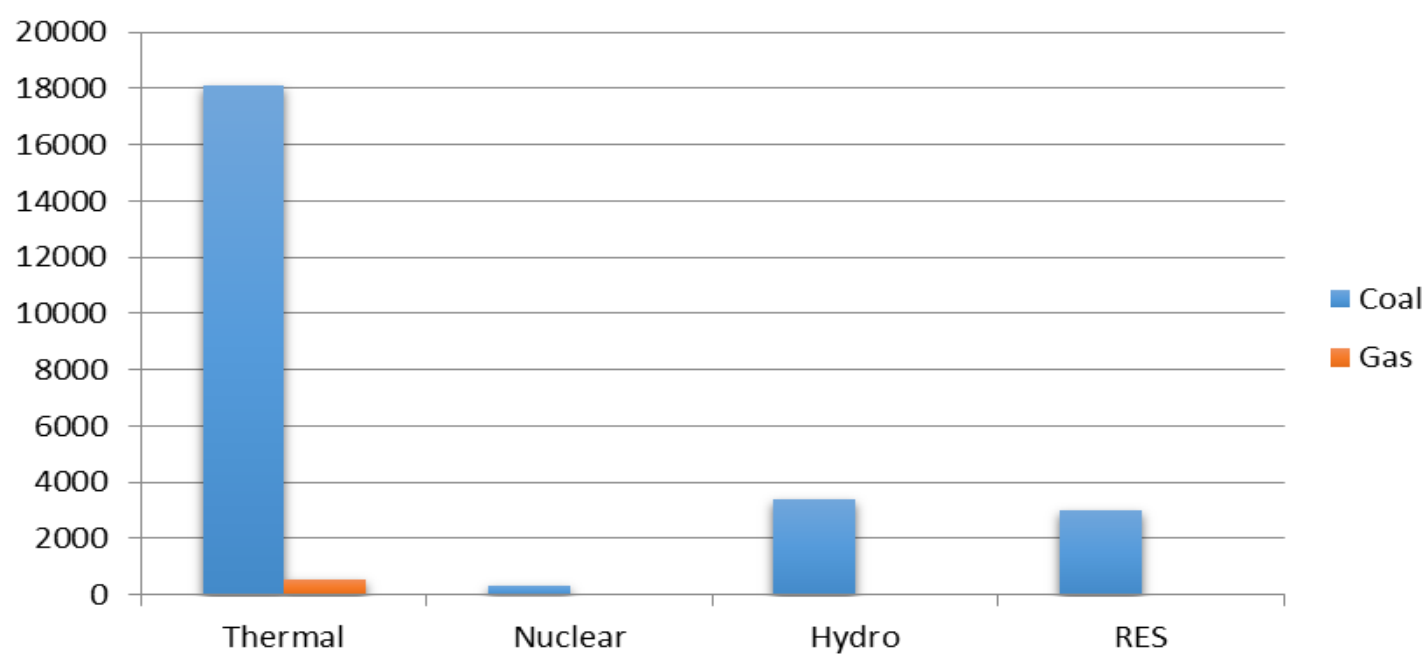

Figure 6. Source wise electricity Generation in Uttar Pradesh [35].

\subsection{Transportation}

Uttar Pradesh being the country's largest consumer base, the market of Electric Vehicles (EVs) is set to boom in this state. The state has the country's fourth largest economy and is among the top 5 manufacturing state with the highest number of Ministry of Micro, Small and Medium enterprises (MSME) units with strong hold in the automobile industry [36].

The state is also known as the State of Expressways, the existing Yamuna and Agra-Lucknow Expressway connect the NCR to the State capital. Poorvanchal Expressway and Bundelkhand. State ranks third in number of vehicles registered in India, sharing 10.3\% of total vehicles registered in India [36]. The capital of the state - Lucknow is one of the 10-cities which are been identified for pilot project of Multi-Modal Electric Public Transport under the Faster Adoption and Manufacturing of (Hybrid) and Electric Vehicles (FAME) India Scheme of GoI [37].

\subsection{Industry}

Uttar Pradesh state has a great access to robust industrial infrastructure having about 15 industrial areas, 12 specialized parks, 4 growth centers \& Industrial Infrastructure Development Centers (IIDC). The state has also proposed 40 IT parks, 2 biotech zones and a knowledge park [38].

Bagasse based Co-Generation Projects in Sugar Mills: UPNEDA started its efforts in 1994 as a catalyst/facilitator to set up power generation projects based on co-generation through bagasse available in the various sugar mills of Uttar Pradesh [39].

Adani Green Energy Private Ltd.: It is one of the largest renewable companies in India, with a current project portfolio of 5,290 MW. The company has commissioned solar power plant of capacity $50 \mathrm{MW}$ in Mahoba and Jhansi district of Uttar Pradesh, under the National Solar Mission Scheme [40]. 


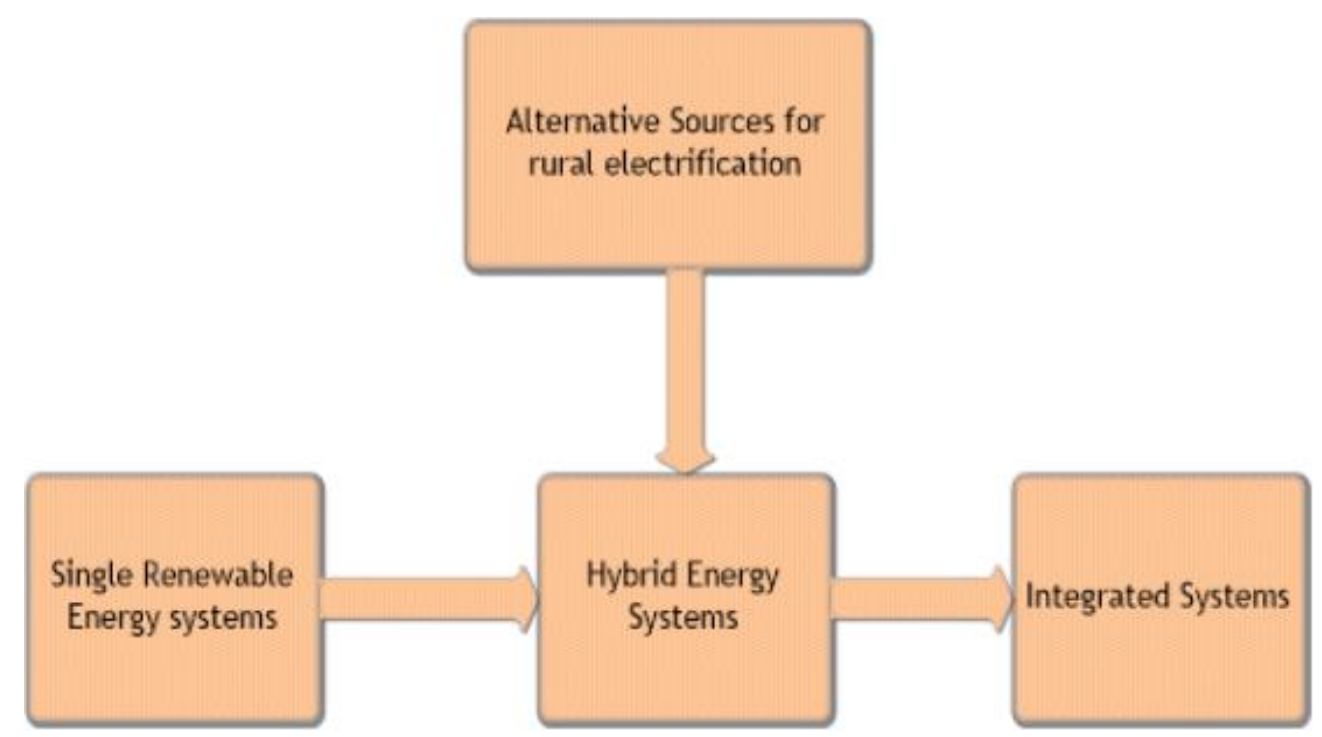

Figure 7. Classification of alternative options for rural electrification.

\subsection{Residential and Commercial Buildings}

The U.S. Green Building Council (USGBC) released the list of India's Top 10 States for LEED (Leadership in Energy and Environmental Design), the world's most widely used green building rating system and Uttar Pradesh is one of them. The state has 82 LEED- certified projects with around 4, 57, 34497 million Certified Gross Square Footage [41].

The list of Green Building projects in the state is shown in Table 2.

Table 2. Green Buildings in the state [42].

\begin{tabular}{lcc}
\hline Project Name & Location & IGBC LEED Rating \\
\hline CESE (Centre for Environmental Sciences and Engineering) Building & Kanpur & NA \\
Patni Knowledge Centre & Noida & LEED Gold \\
Fast Track Building 1 \& 2 & Noida & LEED Gold \\
Spectral Services Offices & Noida & LEED Gold \\
\hline
\end{tabular}

\section{BEST PRACTICES AND VARIOUS TECHNOLOGY OPTIONS AVAILABLE}

Grid Extension is the main driver of rural electrification in the state and off-grid solar power is a potential alternative to grid extension in rural electrification. Most of the rural areas in the state are completely off-grid and for those which are connected also the electricity is erratic and unreliable causing frequent blackouts.

Rural electrification program in India mainly focuses on the extension of the grid structure for the supply of 6 to 8 hours of electricity for a village, whereas, the areas where this is not feasible, use of small distributed generators and networks are used in form of mini grid [43]. Selecting the most appropriate technology for a particular context depends on what characteristics are needed and best suited for the particular environment $[44,45]$. Looking at the diversity of rural villages and households in India, selecting an appropriate rural electrification technology depends on the specific characteristics of the village in consideration [46]. The classification of alternate option for rural electrification are shown in Fig. 7 and discussed in next subsection. 


\subsection{Single Source Renewable Energy System}

The best option for the electrification of standalone rural remote households is the single renewable energy system. These sources include solar photovoltaic, hydro, biomass, biogas, wind etc. The detailed elaboration of each source used for electrification is given below:

\subsection{Solar Home Systems (SHSs)}

The world's largest energy source is sunlight and can be easily accessed with the use of different technologies that evolve today. India is a tropical country and so there is plenty of sunshine all around the country. The power generated by the SPV systems can also be stored in batteries and can be used later after sunset, for different applications. The basic model of a SPV system is shown in Fig. 8 [47].

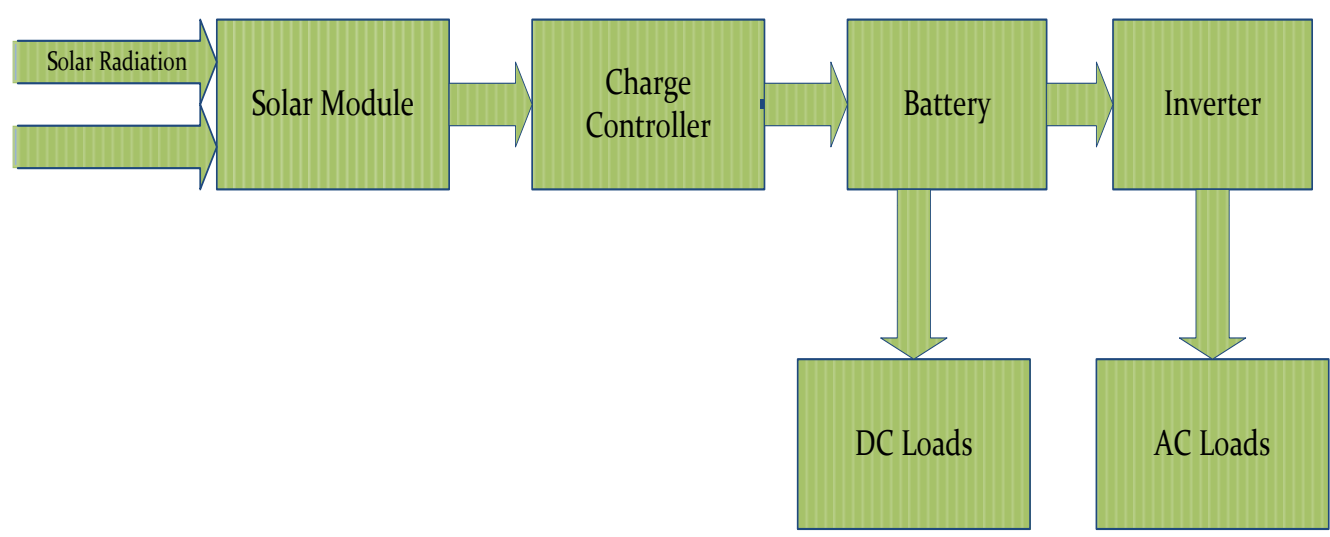

Figure 8. Typical SPV systems and components [47].

\subsubsection{Solar standalone home lightning systems}

Standalone photovoltaic systems which are often referred as the "Solar home systems (SHS)" are an effective mode for supplying power to the remote households which are not connected to the grid. This system is used to meet the basic energy demand of a household and globally, it has provided power to thousands of households in remote locations [47]. The major benefits and contribution of SHS in the standard of living are: Reduction of indoor air pollution and therefore, improvement in the health due to the replacement of kerosene lamps.

\subsubsection{Solar Rooftop Systems}

Millions of homes and commercial buildings in India have rooftops that receive a huge amount of sunlight. The process can be achieved by adding an inverter which converts the DC power generated by the solar panels placed on the rooftop to AC power [48].

\subsubsection{Solar powered agriculture water pump for rural areas}

Solar powered agricultural water pumps along with appropriate technologies and the conservation of water at the local level has a high potential in India and has drawn considerable amount of attention. The farmers or the operators can benefit from the maximum amount of pump during the day. The solar pump drive is independent from the grid and produces no pollution or noise [48]. The basic structure of a solar water pumping system is shown in Fig. 9. 


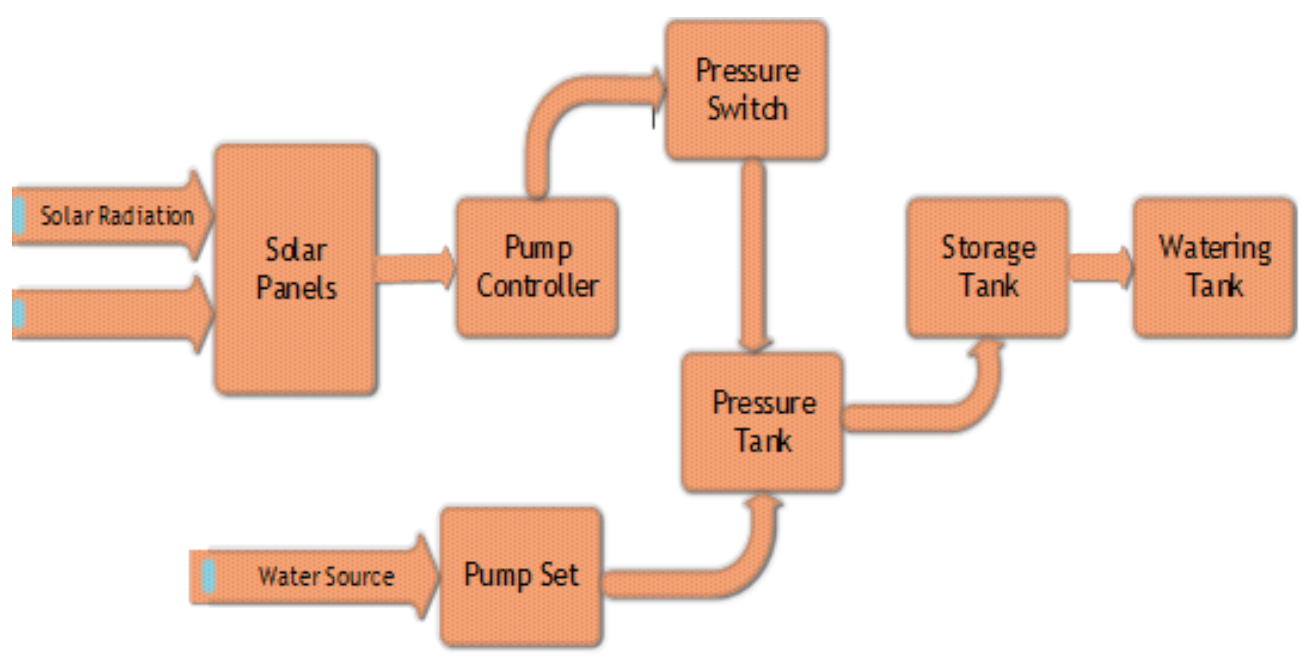

Figure 9. Solar water pumping system [48].

\subsubsection{Solar Lantern}

Solar lantern is an application of SPV technology, which has found good acceptance in rural regions where the power supply is irregular and scarce. It is made of three main components - the solar PV panel, the storage battery and the lamp. The solar energy is converted to electrical energy by the SPV panel and stored in a sealed maintenance-free battery for later use during the night hours. A single charge can operate the lamp for about 4-5 hours [49].

\section{Capacity (MW) / No.}

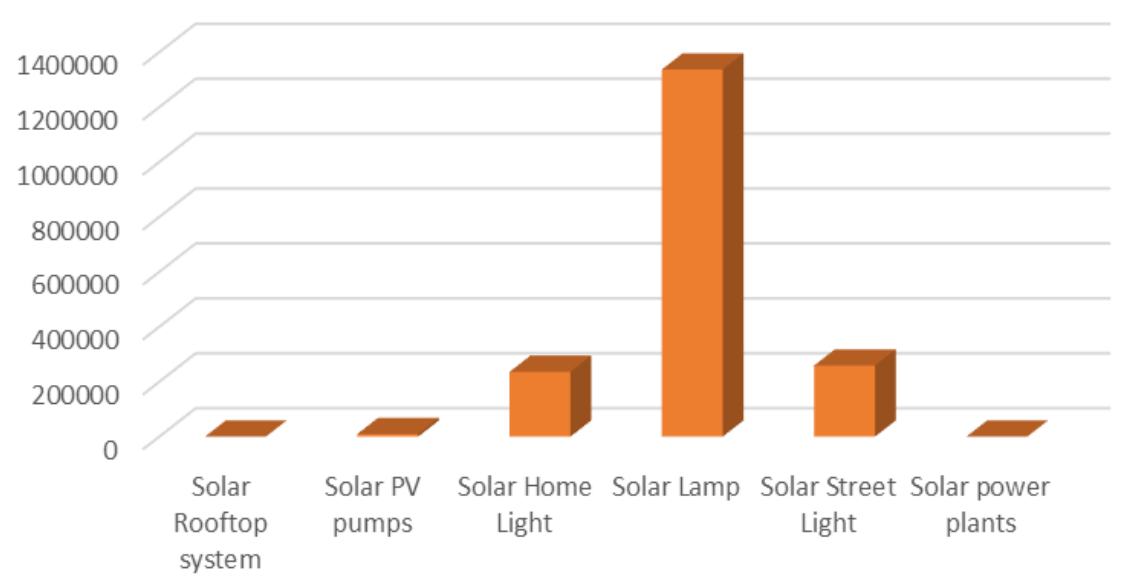

Figure 10. Capacity and status of various solar technology applications in Uttar Pradesh [54].

\subsubsection{Solar Cooker}

Solar cooker is a device which uses the energy of direct sunlight to heat, cook or pasteurize drink and other food materials. Because they use no fuel and cost to operate, many nonprofit organizations are promoting their use worldwide in order to help reduce fuel costs and air pollution, and to slow down the deforestation and desertification caused by gathering firewood for cooking [50].

\subsubsection{Solar Street Lightning}

Solar street lights are raised light sources which are powered by solar panels generally mounted on the lighting structure or integrated into the pole itself. The solar panels charge a rechargeable battery, which 
powers a fluorescent or LED lamp during the night. Most solar lights turn on and off automatically by sensing outdoor light using solar panel voltage. Solar streetlights are designed to work throughout the night. Solar lights installed in windy regions are generally equipped with flat panels to better cope with the winds [51 - 53]. The status of different technologies based on solar energy is mentioned in Fig. 10 [54].

\subsection{Biomass Gasification}

Biomass is a very important source of energy in India due to the benefits it offers like- its renewable nature, wide availability, carbon- neutral and also it has the potential to provide employment to the rural areas. Biomass power generation in the country generates more than 5000 million units of electricity and yearly employment of more than 10 million man-days in the rural areas [55]. Off-grid power capacity from biomass gasifier in three rice mills and other industries including flour mill for meeting captive demand of electricity and thermal applications have been installed in the state of Uttar Pradesh [55]. The total biomass potential of the state is and its types are shown in Fig. 11[18]. The basic schematic process of biomass gasifier-based system in shown in Fig. 12 [56].

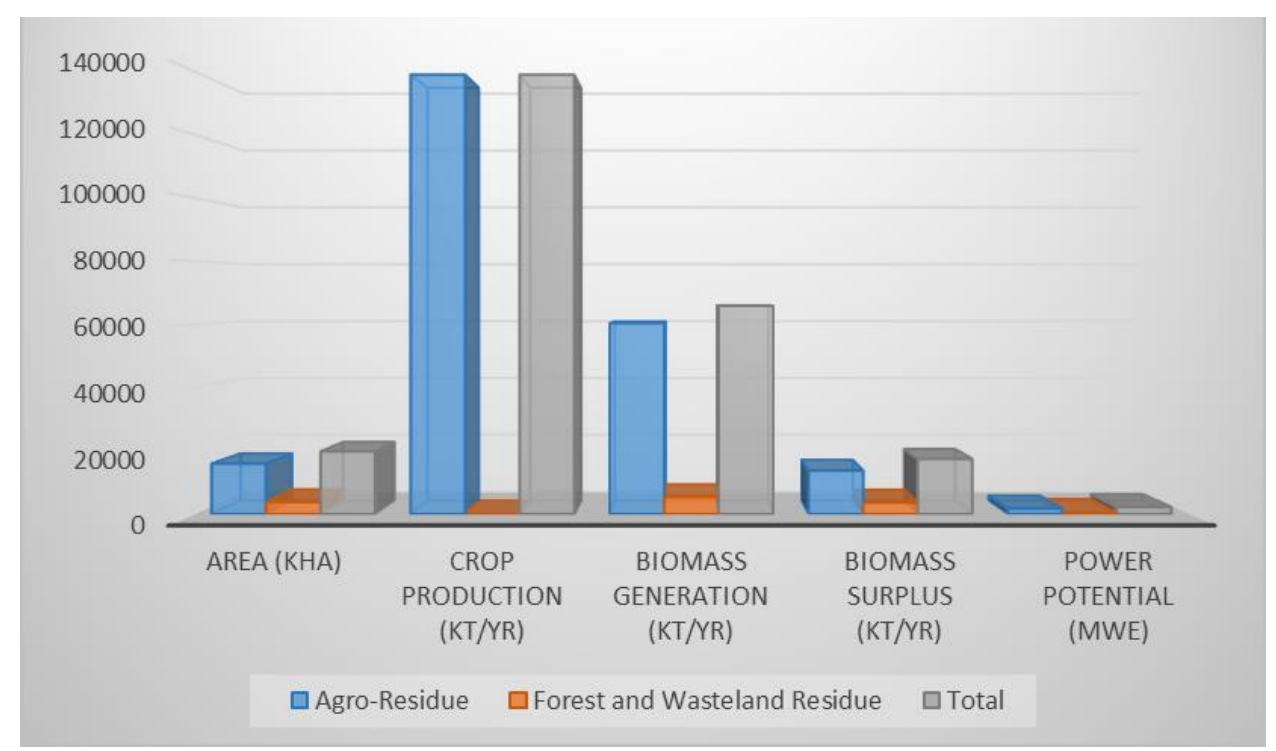

Figure 11. Total biomass potential in Uttar Pradesh [18].

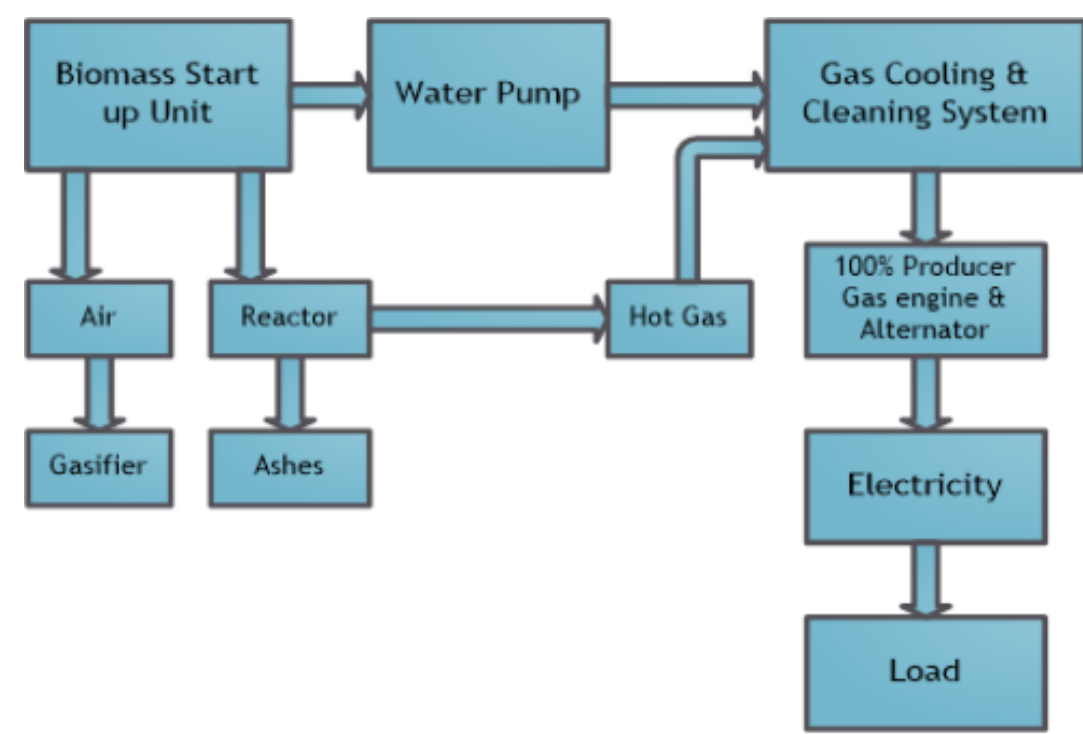

Figure 12. Schematic process of a biomass gasifier-based system [56]. 


\subsection{Biogas System}

Biogas production is a process of converting organic wastes into an organic fertilizer source and a clean renewable biogas having low carbon emission. Biogas is obtained by anaerobic digestion of cattle dung and other loose and leafy organic wastes, further used as an energy source for cooking, lighting and other applications [57]. In a study, the potentiality of biogas production from municipal waste and agricultural residues in a city territory of Dhaka namely Hazaribagh is shown where the potential sources include wastes from two markets, six slaughterhouses, domestic wastes, one poultry farm and three croplands [58].

\subsection{Hydro Power (Small Hydro < 25MW)}

Hydropower uses the Earth's water cycle and kinetic energy of this water to generate the electricity and therefore is an old and renowned RES. Water is evaporated from the Earth's surface and clouds are formed which precipitates back to the Earth and then flow towards the ocean [59]. There is an estimated hydro power potential of $568 \mathrm{MW}$ and from which the small hydro comprises of $167 \mathrm{MW}$ capacity which is being identified at 60 locations in the state $[60,61]$. The numbers and the aggregate capacity of SHPs up to $25 \mathrm{MW}$ in the state are shown in the Fig. 13 [54]. For the rural electrification of remote areas, micro hydro is a very good option as these isolated micro hydro plants are easy to setup and of minimal cost for the supply of electricity [62].

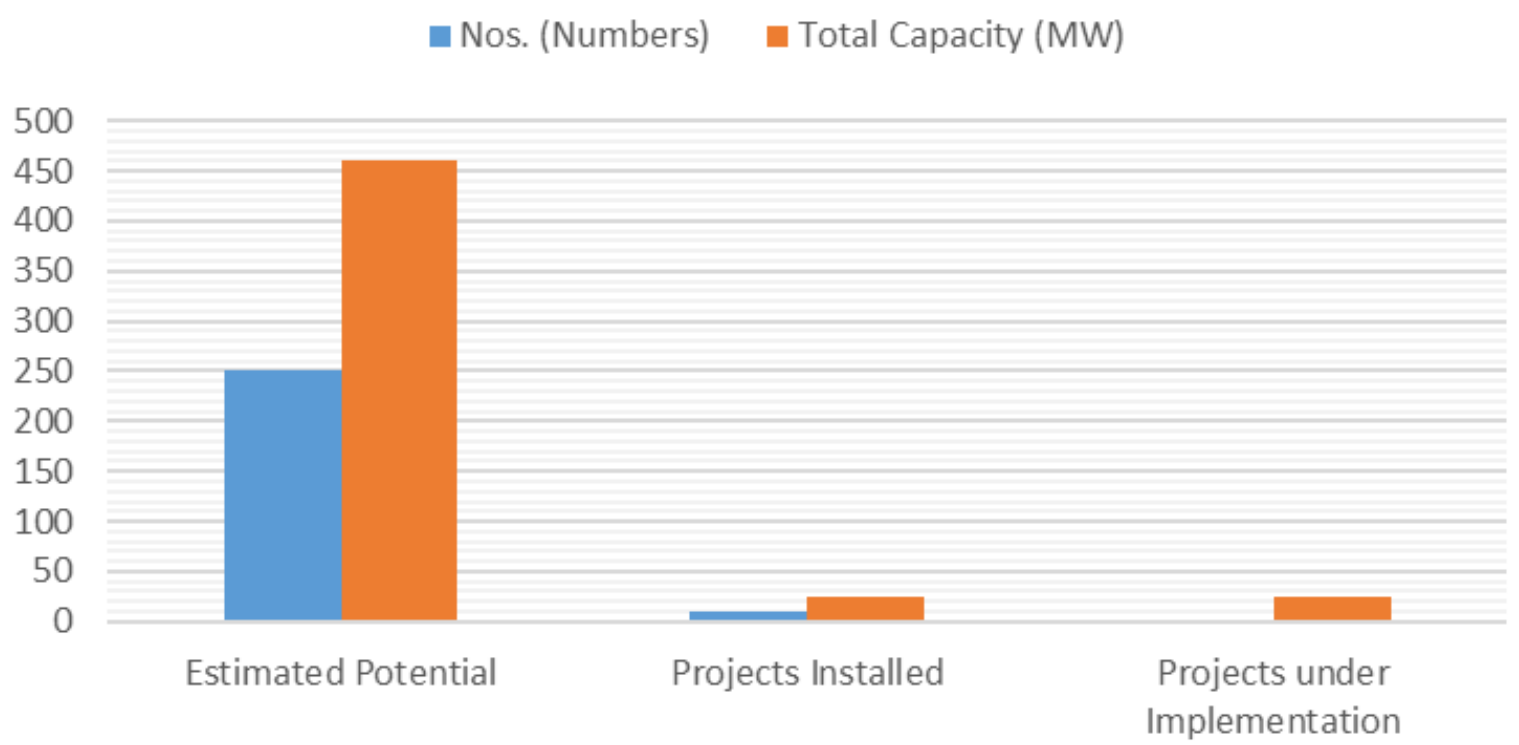

Figure 13. Numbers and cumulative capacity of SHP in the state [54].

\subsection{Wind Power}

The total wind power generation capacity in India as on 31 March 2019 was $36.625 \mathrm{GW}$, which is fourth largest, installed wind power capacity in the world. The various causes of wind are uneven heating of atmosphere by the sun, variations in earth's surface and the rotation of the earth. Mountains, bodies of water, and vegetation all influence due to wind flow patterns [63]. A typical block diagram of such system is shown in Fig. 14 [63]. 


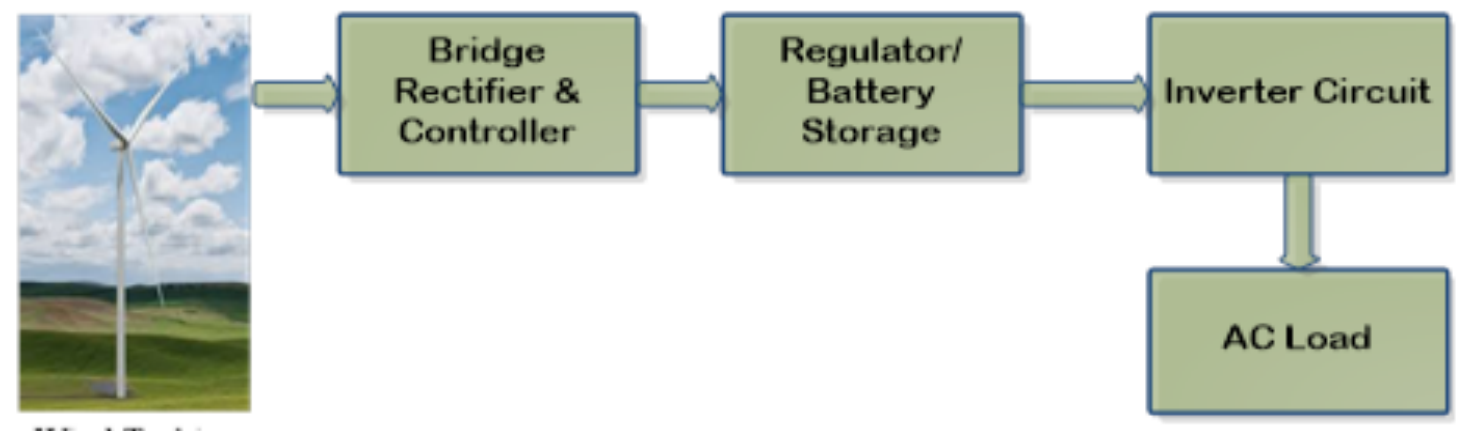

Wind Turbine

Figure 14. Block diagram of small-scale wind turbine system [63].

\subsection{Hybrid Renewable Energy System (HRES)}

Mostly, for the areas which are not having suitable or sufficient amount of RESs, hybrid energy systems (HESs) are best suited option. They are a peerless solution for the continuous supply of the load and for a reliable operation to the areas where grid extension is not possible and the electricity is not available.

An extensive research has already been carried on HESs based on SPV regarding their performance and output planning issues. Agarwal et al. [64] has presented a grid independent PV-Diesel based HES for unelectrified villages of Moradabad district in Uttar Pradesh state. A simple PV-Diesel hybrid system is shown in Fig. 15. Habib et al., [65] presented an optimization method of a PV-wind HES which is used to satisfy the electricity requirements for a given load. Rajkumar et al., [66] presented a technoeconomical optimization of hybrid PV-wind-battery system with the use of Adaptive Neuro-Fuzzy Inference system (ANFIS).

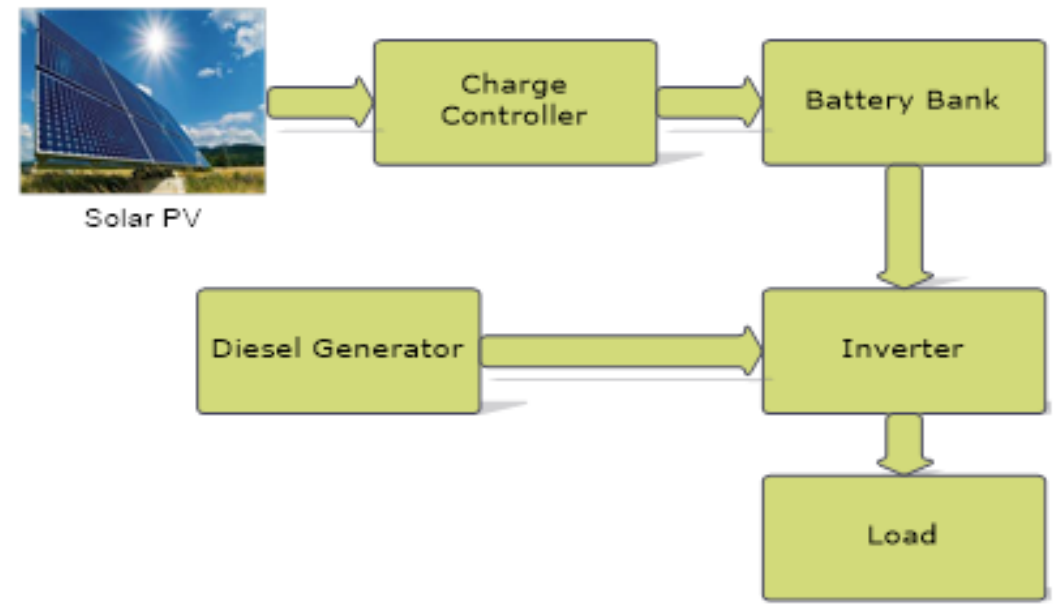

Figure 15. PV-Diesel based hybrid energy system [64].

\subsection{Integrated Renewable Energy System (IRES)}

For the electrification of isolated remote rural areas, the single technology-based systems are the best suited option, but due to the intermittent nature of some RES may not be available in some seasons. Also, these resources are site specific [67]. So, when the demand is increased, these single technology systems experience high cost and low reliability. To reduce this problem, the best option is the IRES [68]. An integrated wind, solar and micro hydro based renewable energy system is represented in Fig.16 [69]. Various planning studies on IRES have been proposed by various researchers for electrification of remote areas [70-71]. 


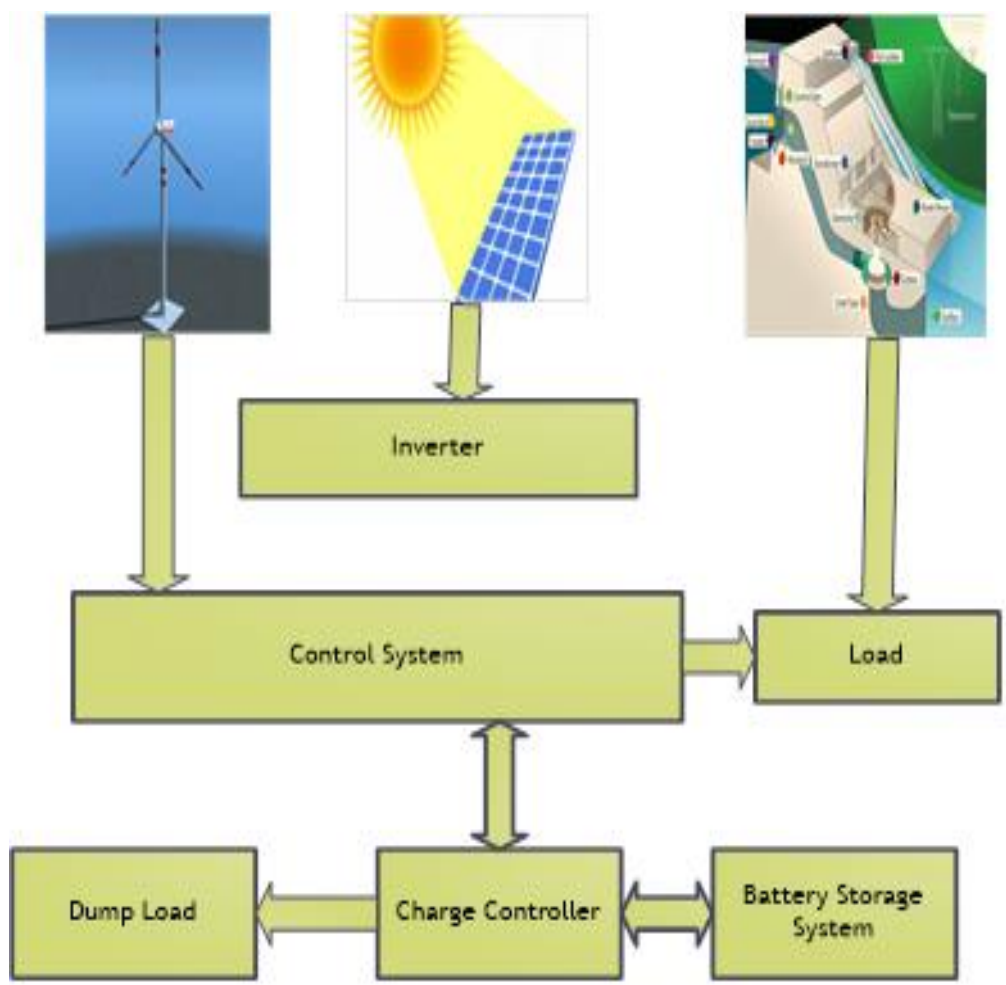

Figure 16. A wind-solar-micro hydro based IRES [69].

\section{REGULATORY FRAMEWORK TO PROMOTE RENEWABLE RESOURCES: POLICIES, PROGRAMS, GOVERNMENT BODIES FUNCTIONS AND STATUS IN THE STATE}

The energy demand in the state has been increasing rapidly along with the development of the state. Due to the limited conventional sources of energy and increasing environmental pollution, renewable energy sources are being given high priority and promotion. A general Framework of the different policies and programs in the state is shown in Fig. 17.

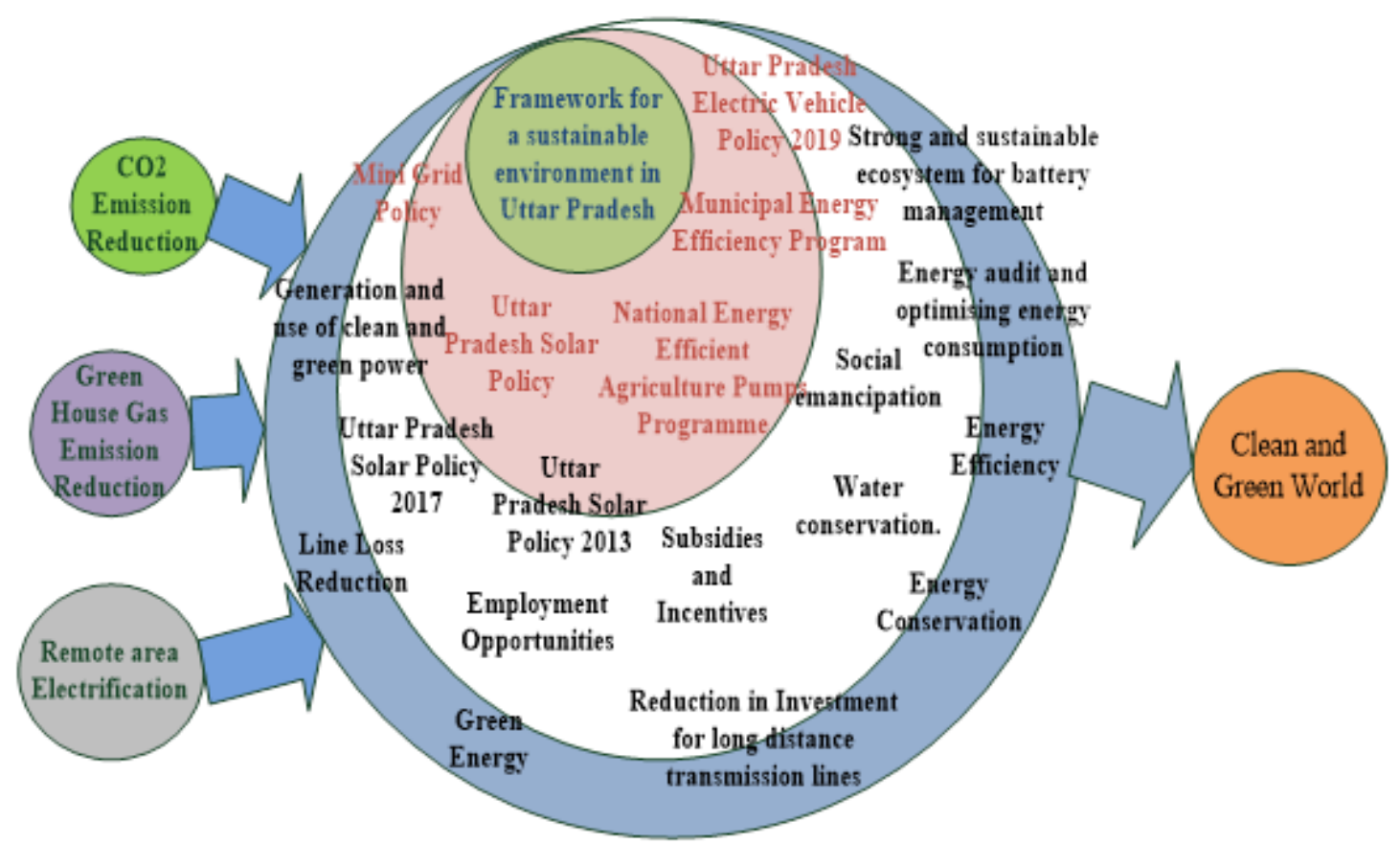

Figure 17. Framework for Sustainable Environment in Uttar Pradesh. 


\subsection{Regulating Agencies / Government Bodies / Policies}

\subsubsection{UPNEDA}

With the increasing development of the state, energy demand has been increasing steadily. Due to the limited conventional energy sources and increasing pollution, emphasis has been done in promoting RESs. UPNEDA has been functioning since 1983, as a nodal agency for the implementation of various schemes promoting the RES development in the state [9]. The basic objectives of this agency are:

Formulation and implementation of projects, standardize the designs of renewable energy systems and provide consultancy services and a technical knowhow to the users, promoters and manufacturers of various systems and devices of RESs and energy conservation.

\subsubsection{Uttar Pradesh Solar Energy Policy 2017}

The State has a solar energy potential of about 22300 MW capacities, which it intends to harness to meet the energy requirements of the state to achieve the solar power generation target which is fixed by MNRE, GoI of 10700 MW [72,73]. The basic objectives of this policy are: Providing environment friendly and power for all. Promotion of research \& development skill development and innovation.

\subsubsection{Mini Grid Policy}

This policy was implemented by UPNEDA in 2016 to provide electricity to remote areas of the state and provide them with the basic necessities of electrification [74]. The basic objectives of this policy are: Promoting the decentralized generation of clean \& green power by harnessing renewable energy. Providing an ensured power supply to nearly 02 crore households in the State to meet the minimum household needs of power.

\subsubsection{Policy Framework for State}

The Electricity Act 2003 mandates the State Electricity Regulatory Commission (SERC) to set the tariffs for renewable energy as well as to issue regulations pertaining to RPO, and set the charges for wheeling, transmission and distribution of electricity. The National Tariff Policy (NTP) 2006 requires the SERCs to fix a minimum percentage of RPO from such sources taking into account availability of such resources in the region and its impact on retail tariffs and procurement by distribution companies at preferential tariffs determined by the SERCs [75].

\subsection{Different Program implemented in State}

\subsubsection{Solar City Program}

The solar city program was implemented by the MNRE, GoI in some cities of the country for the reduction of about $10 \%$ power consumption with the use of RESs. The main objectives of this program are the empowerment of urban local bodies for facing the energy challenges, assessing the current energy situation and spreading awareness about energy among all sections of society. Major cities like - Agra, Moradabad and Allahabad are being identified as the solar cities and besides this Solar City program, GoI is also implementing a Green Campus Scheme for specific urban areas with a population of up to 5 lacs [76].

\subsubsection{Smart City Program}

The Smart Cities Mission (SCM) is a holistic city programme to build 100 cities in India. The objective of this mission is to promote cities that provide core infrastructure and give a decent quality of life to its 
citizens, a clean and sustainable environment or to provide better basic facilities to the citizens of the country. Agra, Allahabad, Aligarh, Bareilly, Jhansi, Kanpur, Lucknow, Moradabad, Rampur, Saharanpur and Varanasi are among the selected cities for this program [77].

\subsubsection{National Biogas Fertilizer Management Program}

This programme was introduced by UPNEDA for the installation of biogas plants of family size of about 2-6 cubic meters efficiency. This one biogas plant could be used for cooking food for around 5 persons in morning and evening and also lightening of 4 to 5 hours a day with 1 lamp. The plant can also provide an equivalent energy of around 18 LPG cylinders per year $[78,79]$.

\subsubsection{Energy Efficiency and Energy Saving Development Program}

Energy saving and Energy Efficiency are an important measure in favour of clean energy. Demand Side Management (DSM) and Energy Efficiency measures in the state in various sectors like - buildings, domestic, industries, agriculture, municipalities etc., a significant amount of electricity is saved. According to the reports of the National Productivity Council, a scope of $13 \%$ to $15 \%$ reduction in electricity usage through demand side measures is there which translates into 15,000 MU of annual energy savings and in turn results in reduction of around 1,500 MW of avoidable capacity in Uttar Pradesh [11].

\section{6. $\mathrm{CO}_{2}$ MITIGATION POTENTIAL ASSESSMENT AND ANALYSIS OF RESS IN UTTAR PRADESH STATE}

In India, the increasing degradation of the environment is due to various factors like the rapid growth in population, poverty, urbanization, industrialization and various other related factors. The main environmental problems in the country are basically related to the air and water pollution mostly in the metro cities and in industrial areas. The various technologies related to RESs have been discussed in previous sections and according to that now the available resources are used to analyze the $\mathrm{CO}_{2}$ emission and the methods to reduce them.

The Indian Government has agreed to reduce the emissions intensity of its gross domestic product (GDP) by an amount of 20-25 percent from 2005 levels by 2020. The Clean Development Mechanism (CDM) under the Kyoto Protocol to United Nations Framework Convention on Climate Change (UNFCCC) provides an opportunity for the Indian power sector to earn revenue through the reduction of GHG, particularly $\mathrm{CO}_{2}$ [80]. CEA accordingly took up to compile a database for all grid-connected power stations in India. The purpose of the database is to establish authentic and consistent quantification of the $\mathrm{CO}_{2}$ emission baseline, which can be readily used by CDM project developers in the Indian power sector [80].

In this section, the $\mathrm{CO}_{2}$ mitigation potential for Uttar Pradesh state has been calculated based on the emission factors described by the CEA database for $\mathrm{CDM}, \mathrm{CO}_{2}$ emission reduction based on RES and the estimated cost saving which can be achieved. This potential has been calculated based on the different emission factors approved by the CDM executive board.

\subsection{Emission Factors used for Analysis}

In Indian context, there are four basic estimation factors [80]:

Weighted Average: This factor describes the average $\mathrm{CO}_{2}$ emitted per unit of electricity generated in the grid. It is calculated by dividing the absolute $\mathrm{CO}_{2}$ emissions of all power stations by the total net generation. 
Simple Operating Margin: The operating margin describes the average $\mathrm{CO}_{2}$ intensity of the existing stations in the grid which are most likely to reduce their output if a CDM project supplies electricity to the grid.

Build Margin: The build margin is used to reflect the average $\mathrm{CO}_{2}$ intensity of the newly built power stations that replaced by a CDM project.

Combined Margin: The combined margin is a weighted average of the simple operating margin and the build margin.

\subsection{Data Extraction and Assessment}

The Annual Data of the database provides the net generation of the station in GWh, the absolute carbon dioxide emissions in metric tonnes, and the specific carbon dioxide emissions in $\mathrm{tCO}_{2} / \mathrm{MWh}$. CEA has compiled the $\mathrm{CO}_{2}$ Database depending upon the generation, fuel consumption and fuel gross calorific value $(\mathrm{GCV})$ data.

Assumptions at Station Level: For the hydro stations, only the gross generation is available, but not the net generation data. Therefore, the CEA standard value for auxiliary power consumption in hydro units $(0.5 \%)$ is applied to derive the net generation from the gross generation data reported by the stations [80]. Assumptions at Unit Level: For some of the stations, the gross generation data is not available at unit level. Therefore, the plant load factor of the respective station is used to derive the gross generation of the units.

In case the fuel consumption and the GCV are not reported at unit level by thermal stations, the specific $\mathrm{CO}_{2}$ emissions of the units coming in the build margin could usually be assumed to be equal to the values of the respective station [80]. Mathematical Model: $\mathrm{CO}_{2}$ emissions of the thermal stations of the state were calculated using the formula below [80]:

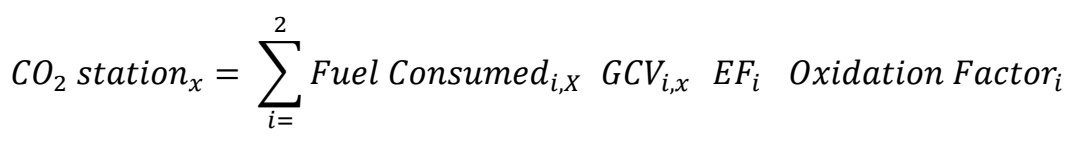

Where, $\mathrm{CO}_{2}, \mathrm{x}=$ Absolute $\mathrm{CO}_{2}$ emission of the station in the given fiscal year ' $\mathrm{x}$ '. Fuel Con $\mathrm{i}, \mathrm{y}=$ Amount of fuel of type i consumed in the fiscal year ' $x$ '. GCVi, $\mathrm{x}=$ Gross calorific value of the fuel $i$ in the fiscal year ' $x$ '. $\mathrm{EFi}=\mathrm{CO}_{2}$ emission factor of the fuel $\mathrm{i}$ based on GCV. Oxidation factor $\mathrm{i}=$ Oxidation factor of the fuel i.

The emission and the oxidation factors used are taken from the $\mathrm{CO}_{2}$ database provided by the CEA [82]. The emission factors for Indian coal is based on the values provided in India's Initial National Communication under the UNFCCC, supported by the results of an analysis of approx. 120 coal samples collected from different Indian coal fields. The values in the National Communication are based on the NCV (Net Calorific Value) and are converted to GCV basis using a formula given by the National Communication.

The specific $\mathrm{CO}_{2}$ emissions are calculated by dividing the absolute emissions to the net generation for the particular station [80].

$$
\text { Specific } \mathrm{CO}_{2}(\text { station })_{x}=\frac{\text { Absolute } \mathrm{CO}_{2}(\text { station })_{x}}{\text { Net Generation }(\text { station })_{x}}
$$

The calculations have been done using the above equations and considering the emission factors described by the CEA in their database for $\mathrm{CO}_{2}$ calculations. Table 3 shows the total generation of Uttar Pradesh state by different sources including coal, gas, nuclear, biomass, cogeneration, hydro, solar and 
Wind. As wind energy generation in the state is not very prominent, we have not considered it. The total generation have been shown for three financial years and for each of the year the total $\mathrm{CO}_{2}$ emission has been calculated considering the respective emission factors for the source. The total generation have been kept same so that a proper analysis can been done. It can be easily seen that by using the renewable energy source, there is a reduction in $\mathrm{CO}_{2}$ emission and also the related cost. The percentage cost saving has also been estimated. The graphical representations of this analysis have been shown in Fig. 18 \& 19. From the above analysis, we can say that by replacing the conventional fuel with the renewable energy sources, a high capital cost can be saved and also can lead to clean and green environment.

Table 3. Total source wise generation, $\mathrm{CO}_{2}$ emissions and the cost of respective sources of generation in Uttar Pradesh state [10, 16, 35, 54].

\begin{tabular}{|c|c|c|c|c|c|c|c|c|c|}
\hline \multirow[t]{2}{*}{ Source } & \multicolumn{3}{|c|}{ Generation Capacity (MW) } & \multicolumn{3}{|c|}{$\mathrm{CO}_{2}$ Emissions (Tonnes) } & \multicolumn{3}{|c|}{ Cost $(\$)$} \\
\hline & $2016-17$ & $2017-18$ & 2018-19 & $2016-17$ & $2017-18$ & $2018-19$ & $2016-17$ & $2017-18$ & $2018-19$ \\
\hline Coal & $\begin{array}{c}17292.5 \\
8\end{array}$ & $\begin{array}{c}18073.7 \\
2\end{array}$ & $\begin{array}{c}18092.9 \\
9\end{array}$ & 17984.28 & 18796.66 & $\begin{array}{c}18816.7 \\
0\end{array}$ & $\begin{array}{c}1,546,648.0 \\
8\end{array}$ & $\begin{array}{c}1616512.7 \\
6\end{array}$ & $\begin{array}{c}1618236.2 \\
0\end{array}$ \\
\hline Gas & 549.49 & 549.49 & 549.49 & 598.94 & 598.94 & 598.94 & $51,508.84$ & $51,508.84$ & $51,508.84$ \\
\hline Nuclear & 289.48 & 289.48 & 289.48 & 0.955 & 0.955 & 0.955 & 82.13 & 82.13 & 82.13 \\
\hline $\begin{array}{l}\text { Biomass } \\
\text { Power }\end{array}$ & 1617 & 1957.50 & 1957.50 & 565.95 & 685.12 & 685.12 & $48,671.70$ & $58,920.75$ & $58,920.75$ \\
\hline $\begin{array}{l}\text { Baggasse } \\
\text { Cogeneratio } \\
n\end{array}$ & 1250 & 160.01 & 158.01 & 283.75 & 36.32 & 35.86 & $24,402.50$ & $3,123.52$ & $3,083.96$ \\
\hline Large Hydro & 2168.30 & 3421.03 & 3368.63 & 1778 & 2805.24 & 2762.27 & 152,908 & $241,250.64$ & $237,555.22$ \\
\hline Small Hydro & 25.5 & 25.01 & 25.01 & 20.91 & 20.58 & 20.58 & 1798.26 & 1769.88 & 1769.88 \\
\hline Solar PV & 850.10 & 891.01 & 960.10 & $\begin{array}{c}2890.34 \mathrm{M} \\
\mathrm{t}\end{array}$ & $\begin{array}{c}3029.43 \mathrm{M} \\
\mathrm{t}\end{array}$ & $3264 \mathrm{Mt}$ & 248,540 & $260,530.98$ & 280,704 \\
\hline Wind & NA & NA & NA & NA & NA & NA & NA & NA & NA \\
\hline
\end{tabular}

Table 4. Estimated cost saving achieved by using solar power in the state [10, 16, 35, 54].

\begin{tabular}{ccccc}
\hline Year & Generation (MW) & $\begin{array}{c}\text { Estimated CO } 2 \text { Emission } \\
\text { Reductions (million t CO2 per year) }\end{array}$ & Estimated Cost Savings (\$) & $\%$ cost saving \\
\hline $2016-17$ & 17292.58 & 58,794 & $5,056,284.00$ & 69.4 \\
$2017-18$ & 18073.72 & $61,450.64$ & $4,833,498.93$ & 66.5 \\
$2018-19$ & 18092.99 & $61,516.16$ & $4,838,652.14$ & 66.5 \\
\hline
\end{tabular}

Table 5: Estimated cost saving achieved by using hydro power in the state [10, 16, 35, 54].

\begin{tabular}{ccccc}
\hline Year & Generation $(\mathrm{MW})$ & $\begin{array}{c}\text { Estimated } \mathrm{CO}_{2} \text { Emission } \\
\text { Reductions }\left(\mathrm{t} \mathrm{CO}_{2} \text { per year }\right)\end{array}$ & Estimated Cost Savings (\$) & \% cost saving \\
\hline $2016-17$ & 17292.58 & $14,179.91$ & $1,219,472.26$ & 26.8 \\
\hline $2017-18$ & 18073.72 & $14,820.45$ & $1,274,558.70$ & 26.8 \\
\hline $2018-19$ & 18092.99 & $14,836.25$ & $1,275,917.50$ & 26.8 \\
\hline
\end{tabular}

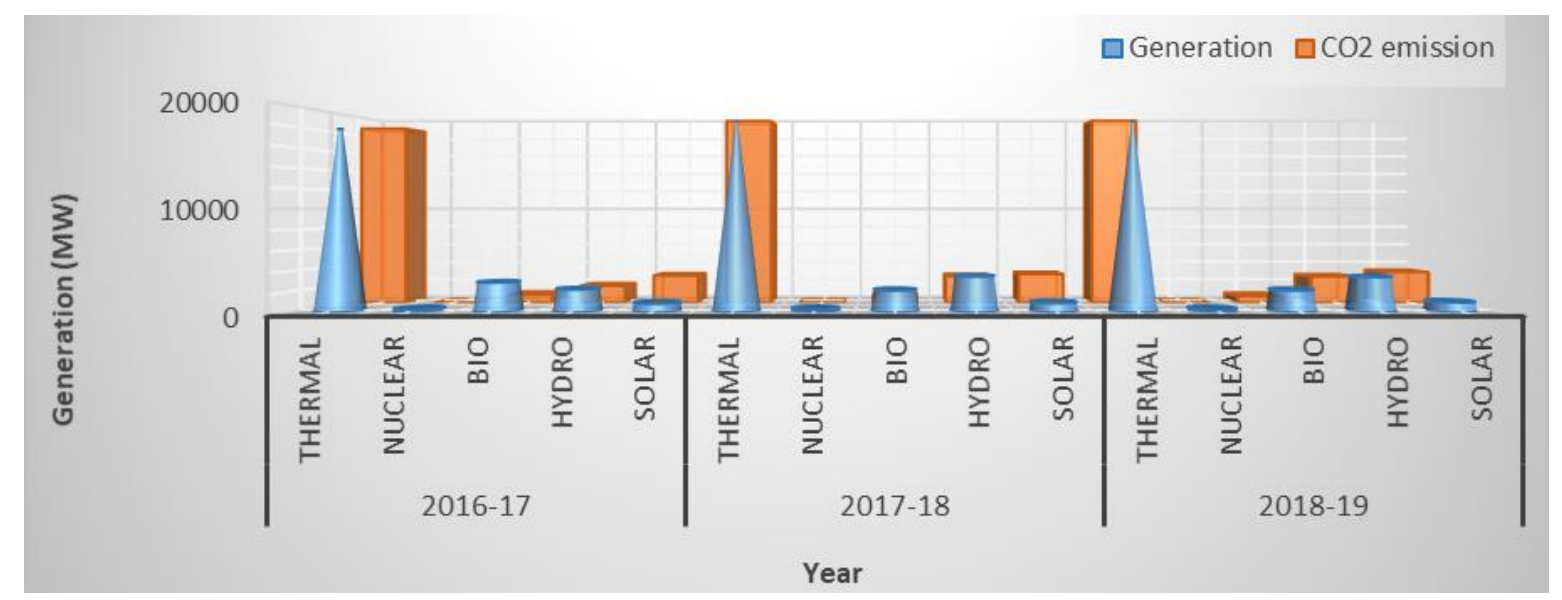

Figure 18. Total generation and $\mathrm{CO}_{2}$ emission for three different years for all the available sources in Uttar Pradesh. 


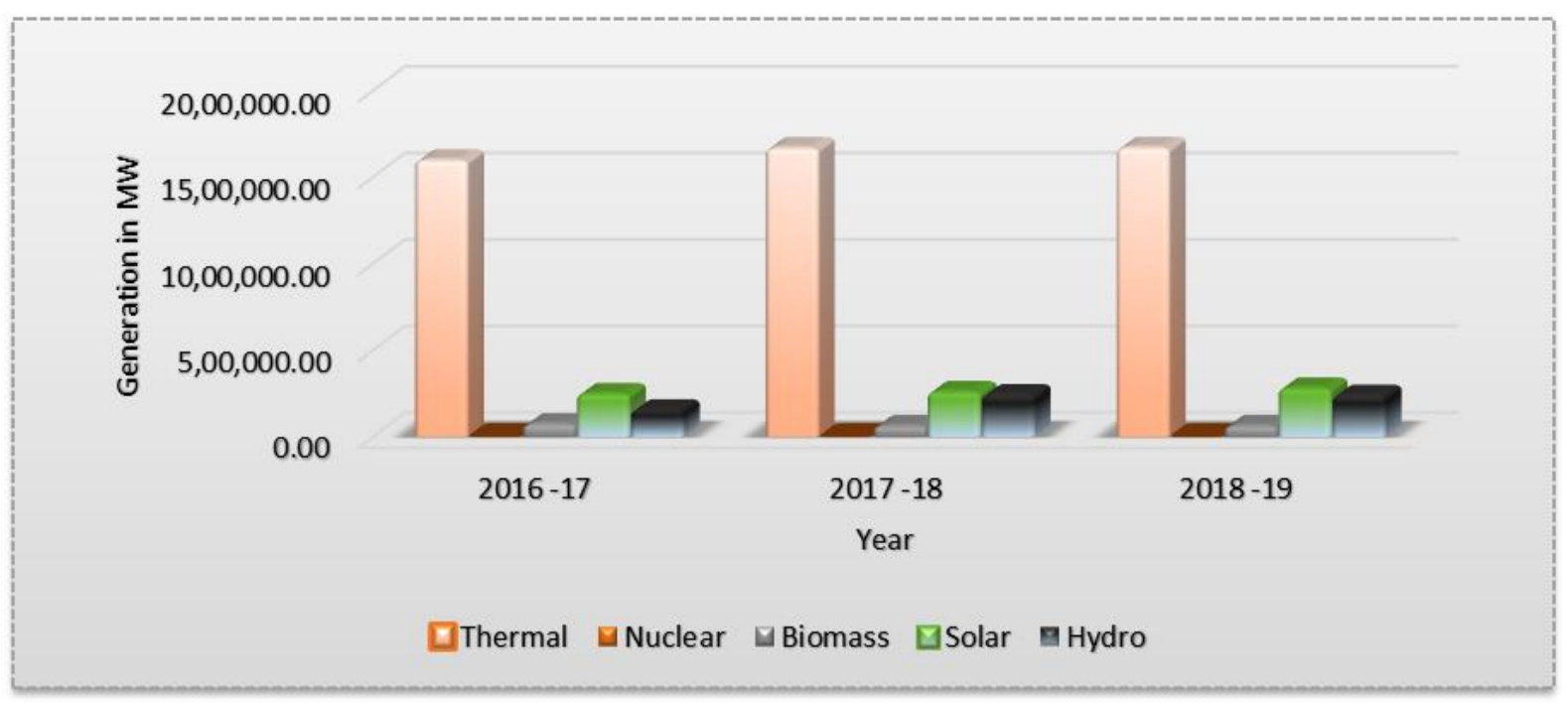

Figure 19. $\mathrm{CO}_{2}$ emission cost of different sources of generation for different years in Uttar Pradesh.

\section{CHALLENGES AND OPPORTUNITIES IN DEVELOPMENT OF RES}

While, benefits of expansion of RES capacity are clear, but the current market, socio-economic structure and regulatory frameworks do not show an efficient means of achieving this goal [81-88].

\subsection{Major Challenges to RES Development in Uttar Pradesh}

\subsubsection{Inappropriate RES Resource estimation}

Despite of the efforts made by the state Government and the amount of RESs available, the proper reports related to the exact amount of RES availability and their estimation is not there. There are many factors like - lack of manpower, proper methods and policies which are involved in the estimation process [85].

\subsubsection{Intermittency associated with RESs.}

Renewable intermittency is basically the unplanned variations due to nature that arises in the power generated by wind/solar energy [81]. This intermittent nature of the RESs is a threat to the stability of the network which leads to problems like power quality, voltage regulation and many more technical issues [82].

\subsubsection{Technical issues related to the operation of RESs.}

Technical issues basically include the lack of infrastructure the inadequacy of technology, inadequate connectivity to the grid faced by the renewable energy development. The major drawback of RES which further leads to many more technical issues is its intermittent and variable nature. Some of these technical issues faced by the grid are power quality, voltage and power fluctuations, reliability \& stability of the system [81].

\subsubsection{Administrative and Regulatory Framework}

Another very important issue in the development of RES is lack of proper administrative and regulatory policies and frameworks. Renewable energy market needs certain clear policies and legal procedures so that the interest of the investors increases [85]. Additionally, these regulatory measures like the 
standardization and coding would enhance the use of renewable energy technologies by minimization of regulatory and technological risk attached with the investments of these RES projects.

\subsubsection{Lack of Technical Abilities}

In developing countries like India, the technical abilities and manpower required for the proper functioning of the RES technologies is less and which a major hindrance in its development [90]. There are very few training programs with respect to these technologies due to which very few technical experts are associated with them [85].

\subsection{Opportunities to Develop RESs in the State}

There are various areas or sectors in the state which can provide opportunities for the development of RESs [85]. The most common sectors are discussed below and are shown in Fig. 20.

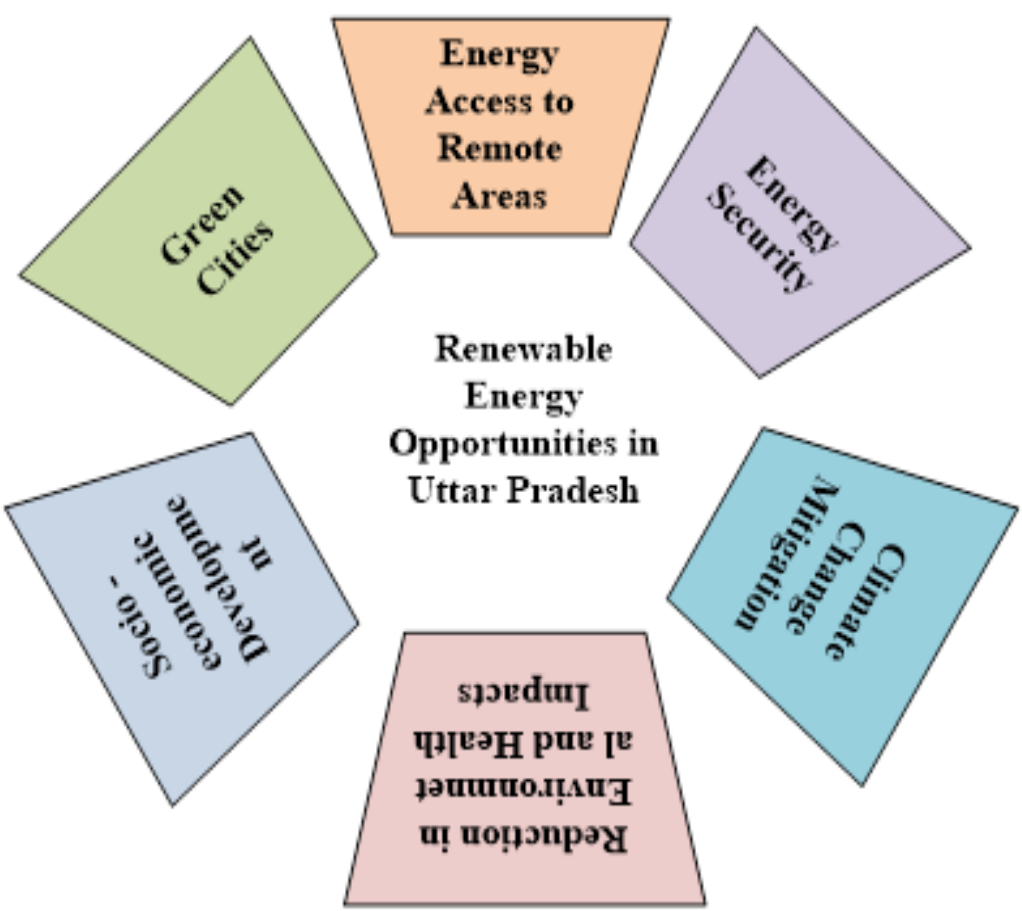

Figure 20. Opportunities for RESs development in Uttar Pradesh.

\subsubsection{Energy Access to Remote Areas}

The state is in its developing stage with electrification reaching to almost every household in the urban areas. The remote areas specially the rural areas have limited access to electricity and the use of RES makes sure that the energy is available to all since these sources are globally distributed around the world. Now, the transition to RES from the conventional fuels in the state has led to many initiatives to improve the energy access in remote areas.

\subsubsection{Energy Security}

Energy security refers to a secured supply of energy without any disruption. The main emphasis in this case should be on the availability of the RESs. Locally available RES can yield energy security by the reduction in the dependency on fossil fuels and increase in different types of supply options. RES is readily available as compared to fossil fuels and less traded in the market. This may also lead to an increase in reliability especially in areas that have insufficient grid connection [86]. 


\subsubsection{Socio-Economic Development of State}

The energy sector of any state is directly related to the economic development and growth of the state. Per capita income is correlated to the per capita energy use and to the human development. Clean and reliable energy is a prerequisite for human development which can contribute to income generation, increase the health and education quality and decrease poverty level [87, 88].

\subsubsection{Climate Change Mitigation}

The most important benefit of using RESs is that it helps in reduction of greenhouse gas emissions. This reduction helps in mitigating the climate change and reduces the various impacts incorporated by these harmful gases associated with fossil fuel generation. The result of the rapidly increasing global temperature is devastating for the environment and necessary actions are taken in the state to mitigate these emissions [88].

\subsubsection{Reduction in Environmental and Health Impacts}

The main three consequences of the climate change - rising sea level, rising temperatures and increased precipitation have the greatest impact on human health. So, the use of RESs will help the mitigation of this climate change and reduction in the severe health impacts on human beings. This will lead to create opportunities to develop more and more clean energy and a green environment [87].

\section{CONCLUSION}

In the present study, firstly an attempt has been made to review the basic concept, growth and current status of renewable energy sources in the country and also in the state. The electrification status of the rural area in Uttar Pradesh state is also presented. An overview of the potential and installed capacity of these resources has been presented. The advantages and disadvantages associated with the production and consumption of different renewable energy sources in the state has been presented.

Different studies and data presented shows that Uttar Pradesh state is rich in biomass and solar potential the most. Uttar Pradesh being one of the largest states of the country has a huge agricultural land and where most of the population depends on agriculture activities and hence large amount of biomass residue is produced. The state is also rich in solar energy, receiving a sufficient amount of solar radiation almost throughout the year. The growth rate of renewable energy production in the state has been increasing rapidly and various policies and schemes have also been introduced for renewable energy technology development. Different technology options available in the state depending upon the rural needs have been presented like- single source energy systems, hybrid energy systems and also the integrated energy system.

To provide electrification to remote rural areas, the best possible solution is to use them as hybrid energy sources and integrated energy sources. An assessment on the $\mathrm{CO}_{2}$ emissions in the state has been presented. Based on this assessment, the related $\mathrm{CO}_{2}$ cost is also calculated. Mitigation potential of various Renewable energy sources available in the state like - solar PV, Hydro, Biomass etc. has been presented and based on this potential the total cost saving for the energy generation for three years is calculated. The respective analysis shows that there is huge amount of cost saving almost $27-67 \%$ and also huge amount of reduction in $\mathrm{CO}_{2}$ emissions by the use of renewable energy sources which leads to reduction in environmental and health impacts. Various kind of issues and challenges associated with the development of RES are been discussed and some solutions and recommendations related to these barriers are also presented. 
New promotional programs and schemes should be on a high priority and different subsidies and incentives should be provided to the rural and un-electrified population. Technical constraints like power quality, stability, voltage and power fluctuations should be considered properly due to the complexity of the system. International market drivers should also be involved in this sector so that more and more knowledge sharing is involved. Various optimization techniques like - ANFIS, ANN, GA, FL should be used to find an optimal solution to the complexity involved with the process. It is more suitable to use the combination of one or more optimization techniques in order to overcome the demerits of individual techniques.

\section{REFERENCES}

[1] Rural Electrification in India - Customer Behavior and Demand. An Initiative by Rockefeller Foundation, Smart Power India and Initiative for sustainable Energy Policy. Feb. 2019.

[2] Internet Web-Site: https://www.bp.com/content/dam/bp/business-sites/en/global/corporate/pdfs/energyeconomicsstatistical-review/bp-stats-review-2018-full-report.pdf, BP Statistical Review. World Energy 2018

[3] BP Statistical Review. Ministry of Power, Aranca Research.

[4] Renewable 2018. Global Status Report (REN21). Central Electricity Authority.

[5] Internet Web-Site: www.forbes.com/sites/suparnadutt/2018/05/07, Forbes Magazine, Accessed on October 2019.

[6] Executive Summary on Power Sector, Central Authority of India, Monthly reports, July 2019.

[7] Internet Web-Site: https://en.wikipedia.org/wiki/Uttar_Pradesh, Wikipedia, Uttar Pradesh, Accessed on October 2019.

[8] Department of Infrastructure and Industrial Development, Directorate of Economics \& Statistics of Uttar Pradesh, Central Statistics Office, Census 2011.

[9] Internet Web-Site: http://upneda.org.in/AboutUs.aspx, Uttar Pradesh New \& Renewable Development Agency, UPNEDA, Accessed on October 2019.

[10] Central Electricity Authority (CEA), State Budget 2018-19.

[11] 24*7 Power for All, Uttar Pradesh. Joint initiative by Government of India and Government of Uttar Pradesh.

[12] Internet Web-Site: https://www.census2011.co.in/census/state/uttar+pradesh.html, CENSUS 2011, Accessed on October 2019.

[13] 24x7 Power for All in Uttar Pradesh Strategies for on-ground action based on ACCESS 2015

[14] Press Information Bureau Government of India. MNRE, 30 April, 2018, PIB Delhi.

[15] Internet Web-Site: http://www.ddugjy.gov.in/portal, Deen Dayal Upadhayaya Gram Jyotii Yojana, Accessed on October 2019.

[16] Central Electricity Authority, Load Balance Report 2018. http://cea.nic.in/reports/annual/lgbr/lgbr-2018.pdf. Accessed on October 2019.

[17] Uttar Pradesh Investor Summit 2018. MNRE. Annual Report 2017-18.

[18] Internet Web-Site: https://biomasspower.gov.in/uttar-pradesh.php, MNRE. Biomass Portal, Accessed on October 2019.

[19] Internet Web-Site: http://upagripardarshi.gov.in, Department of Agriculture. Uttar Pradesh. Accessed on October 2019.

[20] Anil Kumar, Nitin Kumar, Prashant Baredar, Ashish Shukla. A review on biomass energy resources, potential, conversion and policy in India. Renewable and Sustainable Energy Reviews 2015; 45:530-539.

[21] MNRE. https://mnre.gov.in/physical-progress-achievements. Accessed on October 2019.

[22] Internet Web-Site: http://upneda.org.in/micro-hydel.aspx, UPNEDA, Accessed on October 2019.

[23] Internet Web-Site: http://www.upjvn.org, Uttar Pradesh Jal Vidyut Nigam Limited, Accessed on October 2019.

[24] Internet Web-Site: http://upneda.org.in/wind-energy.aspx, UPNEDA, Accessed on October 2019.

[25] Internet Web-Site: http://upneda.org.in/MediaGallery/wind-energy-list-eng\%20new.pdf, UPNEDA, Accessed on October 2019.

[26] Uttar Pradesh Solar Energy Policy-2017. IEA/IRENA Renewables Policies Database.

[27] Internet Web-Site: http://www.synergyenviron.com/, Synergy Enviro Engineers, Accessed on October 2019.

[28] Hoogersmm Gregor. Fuel Cell Technology Handbook. 2003.

[29] E. Taibi, D. Gielen, M. Bazilian. The potential for renewable energy in industrial applications. Renew. Sustain. Energy Rev. 2012; 16: 735-744.

[30] Hydrogen: A Renewable Energy Perspective. A report prepared for the 2nd Hydrogen Energy Ministerial Meeting. International Renewable Energy Agency. September 2019. 
[31] MNRE. Report on Fuel Cell Development in India. 2019.

[32] Internet Web-Site: www.isolaralliance.org, SGF Final Report on Energy Storage System Roadmap for India (2019-2032).

[33] Internet Web-Site: https://www.iea.org/weo2018/, International Energy agency 2018, Accessed on October 2019.

[34] Şen Zekâi. Innovative methodologies in renewable energy: A review. International Journal of Energy Research 2019:1-38.

[35] Internet Web-Site: State-wise installed capacity of Grid Interactive Renewable Power, MNRE, Accessed on 31.12.2018.

[36] Internet Web-Site: https://electricvehicles.in/wp-content/uploads/2019/08/Uttar-Pradesh-Electric-VehiclePolicy-2019.pdf, Uttar Pradesh Electric vehicle Policy, Accessed on November 2019.

[37] Internet Web-Site: https://mercomindia.com/uttar-pradesh-electric-buses/, Mercom India, Accessed on November 2019.

[38] Internet Web-Site: https://msme.gov.in/, Ministry of Micro, Small and Medium Enterprises. 2019

[39] Internet Web-Site: Bio Energy Program. http://upneda.org.in/bio-energy-program.aspx, UPNEDA

[40] Internet Web-Site: www.adanipower.com, Adani Power, Accessed on November 2019.

[41] Internet Web-Site: https://gbci.org/us-green-building-council-releases-annual-top-10-states-leed-india, Green Business Certification Inc., Accessed on November 2019.

[42] Internet Web-Site: http://greenbuildinglocator.in.saint-gobain-glass.com/, Saint Gobain Glass, Accessed on November 2019.

[43] Comello Stephen, D, Reichelstein Stefan, J, Sahoo Anshuman, Tobias S. Schmid. Enabling Mini-Grid Development in Rural India. World Development. 2017.

[44] Kamalapur, GD, Udaykumar, RY. Rural electrification in India and feasibility of Photovoltaic Solar Home Systems. Electrical Power and Energy Systems 2011; 33: 594-599.

[45] A Report on Rural Energy Alternatives in India: Opportunities in Financing and Community Engagement for Renewable Energy Microgrid Projects. Woodgrow Wilson School of Public and International Affairs. 2017.

[46] Oda and Tsujita. The determinants of rural electrification: The case of Bihar in India. Energy Policy. 2011; 39(6):3086-3095.

[47] Ghafoor Abdul and Munir Anjum. Design and economics analysis of an off-grid PV system for household electrification. Renewable and sustainable energy reviews 2015; 42: 496-502.

[48] Internet Web-Site :www.pumpsandsystems.com/pumps/julyaugust-2015-solar-paneled-drives-power-waterpumps-rural-farmers, Pumps and systems, Accessed on October 2019.

[49] Internet Web-Site: Wikipedia. https://en.wikipedia.org/wiki/Solar_lamp

[50] Internet Web-Site: Wikipedia. https://en.wikipedia.org/wiki/Solar_cooker.

[51] Internet Web-Site: Wikipedia. https://en.wikipedia.org/wiki/Solar_rickshaw

[52] Internet Web-Site: Wikipedia. https://en.wikipedia.org/wiki/Solar_streetlightning

[53] Internet Web-Site: Wikipedia. https://en.wikipedia.org/wiki/Solar_dryer

[54] Ministry of New and Renewable Energy (MNRE). Annual Report 2018-2019.

[55] Internet Web-Site: https://mnre.gov.in/biomass-powercogen, MNRE, Accessed on October 2019.

[56] Palit Debajit, Malhotra Ramit, Kumar Atul. Sustainable model for financial viability of decentralized biomass gasifier-based power projects. Energy Pol. 2011;39: 4893-901.

[57] Sodha MS, Ram S, Bansal PK. Effect of PVC greenhouse in increasing the biogas production in temperature cold climate conditions. Energy Conversion Management 1987; 27: 83-90.

[58] Hasan A.S.M Monjurul, Ammenberg Jonas. Biogas potential from municipal and agricultural residual biomass for power generation in Hazaribagh, Bangladesh - A strategy to improve the energy system. Renewable Energy Focus 2019; 29: 14-23.

[59] Internet Web-Site: http://www.eai.in/ref/ae/hyd/hyd.html, Energy Alternatives India (EAI), Accessed on October 2019.

[60] Internet Web-Site:. http://cea.nic.in/, Central Electricity Authority, Accessed on October 2019.

[61] Proceedings of International training course on small hydropower Development. Alternate hydro energy Centre, Indian Institute Of Technology. Roorkee India. Feb 05-16, 2013.

[62] Rojanamon P, Chaisomphob T, Bureekul T. Application of geographical information system to site selection of small run-of-river hydropower project by considering engineering/economic/environmental criteria and social impact. Renewable sustainable Energy Reviews 2009; 13: 2336-2348.

[63] Internet Web-Site: http://www.alternative-energy-news.info/wind-power/. Accessed on October 2019.

[64] Agarwal N, Kumar A, Varun. Optimization of grid independent hybrid PV-diesel-battery system for power generation in remote villages of Uttar Pradesh, India. Energy Sustainable Development. 2013; 17:210-9.

[65] Habib MA, Said SAM, El-Hadidy MA, Al-Zaharna I. Optimization procedure of a hybrid photovoltaic wind energy system. Energy, 1999; 24 (11): 919-1029. 
[66] Rajkumar RK, Rama Chandaramurthy VK, Yong BL, Chia DB. Techno-economical optimization of hybrid pv/wind/battery system using Neuro-Fuzzy. Energy. 2011; 36(8):5148-53.

[67] Akshay Urja Magazine by MNRE, Government of India. 12(5) • April 2019.

[68] Ramakumar R. Integrated renewable energy systems: power engineering review.IEEE. 1995;15(2):10-3.

[69] Chauhan A, Saini R.P. A review on Integrated Renewable Energy System based power generation for standalone applications: Configurations, storage options, sizing methodologies and control. Renewable and Sustainable Energy Reviews. 2014;38: 99-120.

[70] Kanase Patil A.B, Saini R.P, Sharma M.P. Integrated renewable energy systems for off grid rural electrification of remote area. Renew Energy. 2013; 5:1342-9.

[71] Ashenayi K, Ramakumar R. IRES a program to design integrated renewable energy systems. Energy. 1990; $15: 1143-52$.

[72] Internet Web-Site: https://mnre.gov.in/file-manager/UserFiles/state-power-policies/UP-Solar-PowerPolicy.pdf, MNRE. Solar Power Policy

[73] Internet Web-Site: www.isolaralliance.org/docs/UP-solar-policy-2017.pdf, isolar alliance. Uttar Pradesh Solar Policy.

[74] Internet Web-Site: http://www.cbip.org/Policies2019/PD_07_Dec_2018_Policies/UttarPradesh/Minigrid/SummaryUPMiniGrid Policy-2016.pdf, Central Board of Irrigation and Power.

[75] Internet Web-Site: https://mnre.gov.in/renewable-energy-regulatory-framework, MNRE.

[76] Internet Web-Site: http://upneda.org.in/programmes-under-grid-solar.aspx, UPNEDA, Accessed on Nov. 2019.

[77] Ministry of Housing and Urban Affairs. www.mohua.gov.in

[78] Internet Web-Site: http://upneda.org.in/national-biogas-fertilizer.aspx, UPNEDA, Accessed on Nov. 2019.

[79] Internet Web-Site: http://upneda.org.in/biogas-based-power.aspx, UPNEDA, Accessed on Nov. 2019.

[80] $\mathrm{CO}_{2}$ Baseline Database for the Indian Power Sector. Government of India. Ministry of Power Central Electricity Authority. 2019.

[81] Bollen Math, Hassan Fainan. Integration of Distributed Generation in the Power System. A John Wiley \& Sons Publication. 2011.

[82] Chanhome Anuwat, Phichaisawat Sotdhipong, Surachai Chaitusaney. Minimization of voltage fluctuation by considering uncertainty from Renewable Energy resources. 10th International Conference on Electrical Engineering/Electronics, Computer, Telecommunications and Information Technology. 2013.

[83] Kappagantu Ramakrishna, Daniel S. Arul. Challenges and issues of smart grid implementation: A case of Indian scenario. Journal of Electrical Systems and Information Technology 2018;5: 453-467.

[84] Report on Advances Metering Infrastructure and customer systems. Smart grid Investment Grant Program. 2016.

[85] Sen Souvik, Ganguly Saurav. Opportunities, barriers and issues with renewable energy development - A discussion. Renewable and Sustainable Energy Reviews. 2017; 69: 1170 -1181.

[86] Owusu Phebe Asantewaa, Sarkodie Samuel Asumadu. A review of renewable energy sources, sustainability issues and climate change mitigation. Journal of Cogent Engineering. 2016; 3.

[87] Kaygusuz K. Energy for sustainable development: key issues and challenges. Energy Sources 2007; 2:73-83.

[88] UNDP. Human Development Report 2007, United Nations Development Programme, New York, NY, USA; 2007. 


\section{APPENDICES}

\section{APPENDIX 1}

Table 1. District wise list of number of households electrified in Uttar Pradesh [15].

\begin{tabular}{|c|c|c|c|c|c|}
\hline District & $\begin{array}{c}\text { Total } \\
\text { Households }\end{array}$ & $\begin{array}{c}\text { Electrified } \\
\text { Households as } \\
\text { on } 10^{\text {th }} \\
\text { Oct, } 2017\end{array}$ & $\begin{array}{c}\text { Balance Un- } \\
\text { electrified } \\
\text { Households as on } \\
10^{\text {th }} \text { Oct, } 2017\end{array}$ & $\begin{array}{c}\text { Progress from } \\
10^{\text {th }} \text { Oct, } 2017 \\
\text { to } 31^{\text {st }} \mathrm{Jan}, \\
2019\end{array}$ & $\begin{array}{c}\text { Additional } \\
\text { Households } \\
\text { progress from } 1^{\text {st }} \\
\text { Feb } 2019 \text { till date }\end{array}$ \\
\hline Jaunpur & 543636 & 354532 & 189104 & 189000 & 10244 \\
\hline Azamgarh & 531617 & 359052 & 172565 & 172218 & 7108 \\
\hline Gorakhpur & 529442 & 322489 & 206953 & 206866 & 12516 \\
\hline Fatehpur & 460894 & 335410 & 125484 & 126642 & 13755 \\
\hline Saharanpur & 438644 & 325543 & 113101 & 109238 & 2980 \\
\hline Kushinagar & 431458 & 267645 & 163813 & 163255 & 6620 \\
\hline Pratapgarh & 414151 & 297359 & 116792 & 116794 & 13594 \\
\hline Mahrajganj & 404085 & 265174 & 138911 & 135986 & 5684 \\
\hline Allahabad & 401526 & 235639 & 165887 & 178461 & 11061 \\
\hline Kheri & 392121 & 271124 & 120997 & 125952 & 15160 \\
\hline Ghazipur & 379482 & 238271 & 141211 & 137298 & 2542 \\
\hline Siddharthnagar & 371093 & 251805 & 119288 & 119288 & 6624 \\
\hline Rae Bareli & 370175 & 296088 & 74087 & 75469 & 13635 \\
\hline Sitapur & 369627 & 180497 & 189130 & 187312 & 12173 \\
\hline Bahraich & 368221 & 194359 & 173862 & 180341 & 33998 \\
\hline Bijnor & 360706 & 253562 & 107144 & 107695 & 6039 \\
\hline Aligarh & 359534 & 251634 & 107900 & 107900 & 6654 \\
\hline Unnao & 359117 & 167432 & 191685 & 198903 & 22255 \\
\hline Sultanpur & 349470 & 234170 & 115300 & 108929 & 3210 \\
\hline Bulandshahar & 349166 & 229524 & 119642 & 120118 & 14999 \\
\hline Agra & 347573 & 291686 & 55887 & 55887 & 8068 \\
\hline Muzzafarnagar & 347306 & 285892 & 61414 & 61605 & 4631 \\
\hline Basti & 345441 & 219879 & 125562 & 124839 & 5518 \\
\hline Hardoi & 340980 & 145411 & 195569 & 201991 & 11274 \\
\hline Varanasi & 332187 & 212270 & 119917 & 122277 & 3071 \\
\hline Ballia & 329423 & 193773 & 135650 & 132605 & 2977 \\
\hline Chandauli & 326476 & 248354 & 78122 & 78155 & 2777 \\
\hline Barabanki & 301600 & 182417 & 119183 & 113696 & 5738 \\
\hline Meerut & 299230 & 247464 & 51766 & 51925 & 3468 \\
\hline Moradabad & 290410 & 174970 & 115440 & 115968 & 12348 \\
\hline Sonbhadra & 283956 & 110863 & 173093 & 167297 & 668 \\
\hline Faizabad & 274882 & 174465 & 100417 & 95972 & 5324 \\
\hline Gonda & 268418 & 135113 & 133305 & 132031 & 26513 \\
\hline Shahjahanpur & 267342 & 130989 & 136353 & 134247 & 9859 \\
\hline Mirzapur & 266858 & 145182 & 121676 & 120833 & 10575 \\
\hline Bareilly & 262046 & 158446 & 103600 & 115564 & 6718 \\
\hline Balrampur & 255313 & 177023 & 78290 & 73900 & 9872 \\
\hline $\begin{array}{l}\text { Ambedkar } \\
\text { Nagar }\end{array}$ & 255268 & 198238 & 57030 & 55705 & 1696 \\
\hline Lucknow & 254665 & 165697 & 88968 & 89969 & 1114 \\
\hline Mau & 240346 & 155025 & 85321 & 85297 & 1535 \\
\hline Pilibhit & 236024 & 165315 & 70709 & 69350 & 5761 \\
\hline Mathura & 228287 & 151564 & 76723 & 76723 & 4664 \\
\hline $\begin{array}{l}\text { Mahamaya } \\
\text { Nagar }\end{array}$ & 223574 & 172465 & 51109 & 51109 & 2654 \\
\hline Amethi & 220961 & 153205 & 67756 & 61415 & 2632 \\
\hline $\begin{array}{l}\text { Jyotiba Phule } \\
\text { Nagar }\end{array}$ & 217374 & 140576 & 76798 & 75747 & 6498 \\
\hline Rampur & 216354 & 113653 & 102701 & 103012 & 6039 \\
\hline Baghpat & 211114 & 190371 & 20743 & 20947 & 3192 \\
\hline Firozabad & 210786 & 136637 & 74149 & 74149 & 2514 \\
\hline
\end{tabular}




\begin{tabular}{|c|c|c|c|c|c|}
\hline Sambhal & 206047 & 114210 & 91837 & 92869 & 8179 \\
\hline $\begin{array}{ll}\text { Sant } & \text { Kabir } \\
\text { Nagar } & \end{array}$ & 195987 & 105047 & 90940 & 91014 & 3899 \\
\hline Banda & 189438 & 82811 & 106627 & 106627 & 669 \\
\hline Auraiya & 188849 & 114727 & 74122 & 74122 & 2061 \\
\hline Farrukhabad & 187254 & 98945 & 88309 & 88703 & 3675 \\
\hline Budaun & 185888 & 101969 & 83919 & 84208 & 11393 \\
\hline Mainpuri & 184592 & 110738 & 73854 & 73854 & 8559 \\
\hline Kanpur Nagar & 178464 & 111725 & 66739 & 66739 & 6641 \\
\hline Kanpur Dehat & 174969 & 90634 & 84335 & 84335 & 5694 \\
\hline Shamli & 168080 & 141489 & 26591 & 26966 & 1575 \\
\hline Kannauj & 166063 & 86504 & 79559 & 79559 & 6365 \\
\hline Jalaun & 165318 & 78646 & 86672 & 86672 & 4250 \\
\hline $\begin{array}{ll}\text { Sant } & \text { Ravidas } \\
\text { Nagar } & \end{array}$ & 162082 & 96086 & 65996 & 67817 & 2002 \\
\hline Shrawasti & 148867 & 90149 & 58718 & 52811 & 1686 \\
\hline Chitrakoot & 143290 & 53895 & 89395 & 89395 & 233 \\
\hline Kaushambi & 137842 & 78200 & 59642 & 59649 & 4275 \\
\hline Etah & 137503 & 77044 & 60459 & 60459 & 7624 \\
\hline Jhansi & 135325 & 84071 & 51254 & 51254 & 2939 \\
\hline Hamirpur & 135171 & 74241 & 60930 & 60544 & 3199 \\
\hline Etawah & 134965 & 83508 & 51457 & 52063 & 1344 \\
\hline Lalitpur & 123567 & 63228 & 60339 & 59725 & 3395 \\
\hline Mahoba & 120085 & 81457 & 38628 & 38628 & 3731 \\
\hline Ghaziabad & 118498 & 102253 & 16245 & 16305 & 1951 \\
\hline Hapur & 114949 & 84113 & 30836 & 31255 & 2105 \\
\hline $\begin{array}{l}\text { Kanshiram } \\
\text { Nagar }\end{array}$ & 112821 & 66206 & 46615 & 46615 & 8191 \\
\hline $\begin{array}{l}\text { Gautam Buddha } \\
\text { Nagar }\end{array}$ & 85544 & 65872 & 19672 & 20276 & 3332 \\
\hline Total & $2,05,54,140$ & $1,32,07,298$ & $73,46,842$ & $73,45,170$ & $5,00,930$ \\
\hline
\end{tabular}




\section{APPENDIX 2}

Table 3: Various RES technology options available in the state.

\begin{tabular}{|c|c|c|c|c|c|c|c|c|c|c|c|c|c|}
\hline ì & 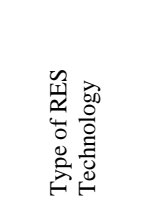 & 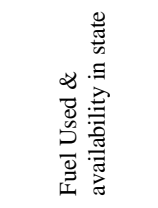 & 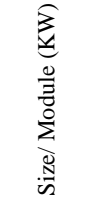 & 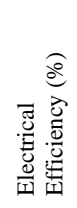 & 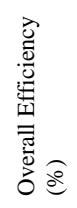 & 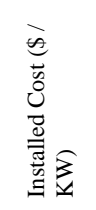 & 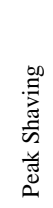 & 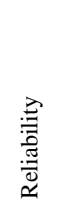 & 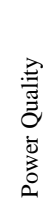 & 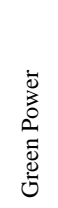 & 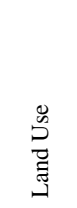 & $\stackrel{\mathscr{E}}{\sum^{\frac{0}{2}}}$ & 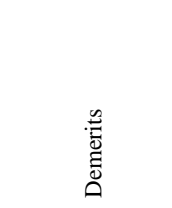 \\
\hline 1 & 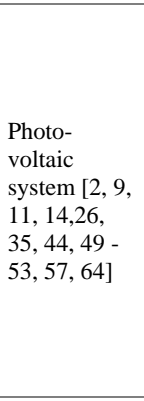 & $\begin{array}{l}\text { Sunlight, } \\
(4.27 \\
\mathrm{kWh} / \mathrm{m} 2 / \text { day } \\
-5.2 \\
\mathrm{kWh} / \mathrm{m} 2 / \text { day })\end{array}$ & $\begin{array}{l}0.02- \\
1000+\end{array}$ & $\begin{array}{l}15- \\
17 \\
\%\end{array}$ & $\begin{array}{l}40- \\
45 \\
\%\end{array}$ & $\begin{array}{l}4500- \\
6000\end{array}$ & No & No & No & Yes & $\begin{array}{l}100 \\
\text { sq.ft. } \\
-4 \\
\text { acres }\end{array}$ & $\begin{array}{l}\text { Remote } \\
\text { standalones } \\
\text { electrification } \\
\text { possible } \\
\text { Readily } \\
\text { available } \\
\text { Negligible } \\
\text { operation } \\
\text { Suitable for } \\
\text { small - large } \\
\text { applications } \\
\text { Reduce } \\
\text { greenhouse } \\
\text { gas emission }\end{array}$ & $\begin{array}{l}\text { High capital } \\
\text { cost } \\
\text { Weather } \\
\text { dependent } \\
\text { Intermittent } \\
\text { nature } \\
\text { Additional } \\
\text { component } \\
\text { required } \\
\text { Large area of } \\
\text { land required }\end{array}$ \\
\hline 2 & $\begin{array}{l}\text { Wind } \\
{[2,4,21,24} \\
-25,33,54, \\
59,69]\end{array}$ & $\begin{array}{l}\text { Wind, }(1.5 \\
\mathrm{m} / \mathrm{s}-4.1 \mathrm{~m} / \mathrm{s})\end{array}$ & $\begin{array}{l}0.1- \\
3000+\end{array}$ & & $\begin{array}{l}50- \\
80 \\
\%\end{array}$ & $\begin{array}{l}3000- \\
4 \\
\text { million }\end{array}$ & No & No & No & Yes & $\begin{array}{l}0.375 \\
\text { acres } \\
- \\
2.25 \\
\text { acres }\end{array}$ & $\begin{array}{l}\text { Readily } \\
\text { available } \\
\text { Environment } \\
\text { friendly } \\
\text { Reduce fossil } \\
\text { fuel } \\
\text { consumption } \\
\text { Small land } \\
\text { footprint } \\
\text { Suitable for } \\
\text { remote area } \\
\text { electrification } \\
\text { Low } \\
\text { maintenance } \\
\text { and running } \\
\text { costs }\end{array}$ & $\begin{array}{l}\text { Intermittent } \\
\text { nature } \\
\text { High } \\
\text { installation cost } \\
\text { Threat to } \\
\text { wildlife } \\
\text { Weather } \\
\text { dependent }\end{array}$ \\
\hline 3 & $\begin{array}{l}\text { Biomass } \\
\text { Gasification } \\
{[1-2,8,15,} \\
18,20,44, \\
46,55,58,78 \\
-80]\end{array}$ & $\begin{array}{l}\text { Fuel wood, } \\
\text { crops residue, } \\
\text { agro industrial } \\
\text { residue, } \\
1765 \text { MW }\end{array}$ & $\begin{array}{l}5- \\
20,000\end{array}$ & $\begin{array}{l}15- \\
25 \\
\%\end{array}$ & $\begin{array}{l}60- \\
75 \\
\%\end{array}$ & $\begin{array}{l}1500- \\
3000\end{array}$ & No & No & No & Yes & NA & $\begin{array}{l}\text { Address waste } \\
\text { needs as well } \\
\text { as energy } \\
\text { needs } \\
\text { Generated } \\
\text { from local } \\
\text { sources } \\
\text { Include } \\
\text { variety of } \\
\text { organic } \\
\text { sources } \\
\text { Reduce fossil } \\
\text { fuel } \\
\text { consumption }\end{array}$ & $\begin{array}{l}\text { Cause health } \\
\text { hazards } \\
\text { Deforestation } \\
\text { Source of } \\
\text { emission and } \\
\text { air pollution } \\
\text { Unpredictability } \\
\text { \& } \\
\text { seasonability } \\
\text { Land use }\end{array}$ \\
\hline 4 & $\begin{array}{l}\text { Biogas [1-2, } \\
8,15,18,20 \text {, } \\
44,46,55, \\
57-58,78- \\
80]\end{array}$ & $\begin{array}{l}\text { Methane, } \\
\text { Carbon } \\
\text { Dioxide }\end{array}$ & $\begin{array}{l}3-250 \\
\mathrm{KV}\end{array}$ & $\begin{array}{l}30- \\
40 \\
\%\end{array}$ & $\begin{array}{l}40- \\
90 \%\end{array}$ & $\begin{array}{l}15000- \\
11.35 \\
\text { cr. }\end{array}$ & No & No & No & Yes & NA & $\begin{array}{l}\text { Eco friendly } \\
\text { Reduce soil } \\
\text { and water } \\
\text { pollution } \\
\text { Produce } \\
\text { organic } \\
\text { fertilizer } \\
\text { Simple and } \\
\text { low cost } \\
\text { Healthy } \\
\text { cooking } \\
\text { alternative }\end{array}$ & $\begin{array}{l}\text { Contains } \\
\text { impurities } \\
\text { Temperature } \\
\text { dependent }\end{array}$ \\
\hline 5 & $\begin{array}{l}\text { Small Hydro } \\
\text { Power } \\
{[9,21-23,} \\
33,44,61- \\
62,69-70, \\
90]\end{array}$ & Water & $\begin{array}{l}5- \\
25,000\end{array}$ & & $\begin{array}{l}90- \\
98 \\
\%\end{array}$ & $\begin{array}{l}10,000 \\
- \\
13,000\end{array}$ & No & Yes & Yes & Yes & NA & $\begin{array}{l}\text { Helps fight } \\
\text { climate } \\
\text { changes } \\
\text { Uses other } \\
\text { renewable } \\
\text { sources } \\
\text { Improves the } \\
\text { air we breathe } \\
\text { Uses water } \\
\text { which is not } \\
\text { subjected to } \\
\text { market } \\
\text { fluctuations }\end{array}$ & $\begin{array}{l}\text { Effect land use } \\
\text { Depends on } \\
\text { precipitation } \\
\text { level } \\
\text { Alter the water } \\
\text { temperature and } \\
\text { river flow }\end{array}$ \\
\hline
\end{tabular}




\begin{tabular}{|c|c|c|c|c|c|c|c|c|c|c|c|c|c|}
\hline 6 & $\begin{array}{l}\text { Solar- } \\
\text { Thermal [2, } \\
9,11,14,15 \text {, } \\
26,35,44, \\
49-53,57, \\
64,72]\end{array}$ & Sunlight & $\begin{array}{l}1000- \\
80,000\end{array}$ & $\begin{array}{l}30- \\
40 \\
\%\end{array}$ & $\begin{array}{l}50- \\
75 \\
\%\end{array}$ & & No & No & No & Yes & NA & $\begin{array}{l}\text { No fuel cost } \\
\text { Predictable } \\
\text { Pollution free } \\
\text { Use existing } \\
\text { industrial base }\end{array}$ & $\begin{array}{l}\text { High cost } \\
\text { Water issue } \\
\text { Ecological and } \\
\text { cultural issues } \\
\text { Limited } \\
\text { locations and } \\
\text { size } \\
\text { 120imitations }\end{array}$ \\
\hline 7 & $\begin{array}{l}\text { Battery } \\
\text { Storage } \\
{[29,36,44 \text {, }} \\
47,64,69- \\
70]\end{array}$ & NA & $\begin{array}{l}100- \\
5000\end{array}$ & NA & $\begin{array}{l}70- \\
75 \\
\%\end{array}$ & $\begin{array}{l}100- \\
200\end{array}$ & Yes & Yes & Yes & Yes & NA & $\begin{array}{l}\text { High energy } \\
\text { density } \\
\text { Low } \\
\text { maintenance } \\
\text { Variety of } \\
\text { types } \\
\text { available }\end{array}$ & $\begin{array}{l}\text { Protection } \\
\text { required } \\
\text { Ageing } \\
\text { Cost } \\
\text { Transportation }\end{array}$ \\
\hline 8 & $\begin{array}{l}\text { Fuel cell } \\
{[28,30-31]}\end{array}$ & Hydrogen & $\begin{array}{l}0.1- \\
2 \mathrm{MW}\end{array}$ & $\begin{array}{l}40- \\
60 \%\end{array}$ & $\begin{array}{l}80- \\
85 \%\end{array}$ & $60-500$ & Yes & Yes & Yes & Yes & NA & $\begin{array}{l}\text { High power } \\
\text { density } \\
\text { High } \\
\text { efficiency } \\
\text { conversion } \\
\text { Quiet } \\
\text { operation } \\
\end{array}$ & $\begin{array}{l}\text { High cost } \\
\text { Fuel required }\end{array}$ \\
\hline 9 & $\begin{array}{l}\text { Electric } \\
\text { Vehicle } \\
{[35-37,} \\
85,86]\end{array}$ & $\begin{array}{l}\text { Battery or } \\
\text { Fuel Cell }\end{array}$ & & NA & $\begin{array}{l}70- \\
75 \%\end{array}$ & $\begin{array}{l}350- \\
10,000\end{array}$ & Yes & Yes & Yes & Yes & NA & $\begin{array}{l}\text { No gas } \\
\text { required } \\
\text { No emission } \\
\text { Safe to drive } \\
\text { Savings } \\
\text { Low } \\
\text { maintenance }\end{array}$ & $\begin{array}{l}\text { Short driving } \\
\text { range } \\
\text { and speed } \\
\text { Long recharge } \\
\text { time } \\
\text { Recharge points } \\
\text { required }\end{array}$ \\
\hline
\end{tabular}

